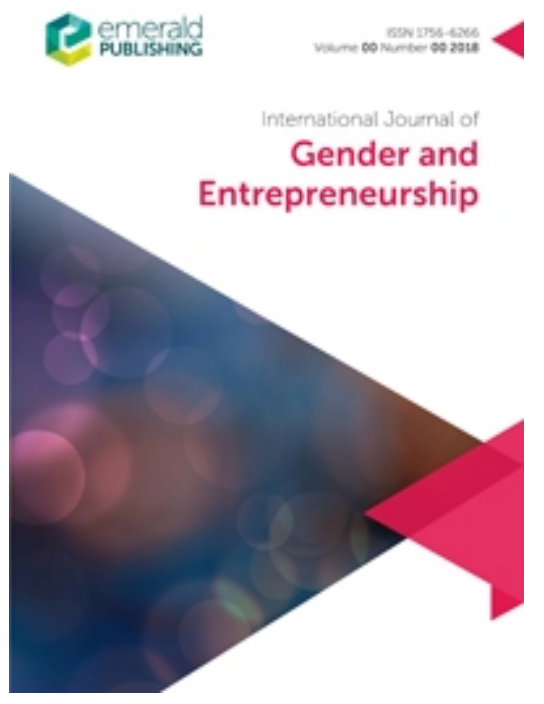

\title{
Empowering Vulnerable Microfinance Women Through Entrepreneurship: Opportunities, Challenges and the Way forward
}

\begin{tabular}{|r|l|}
\hline Journal: & International Journal of Gender and Entrepreneurship \\
\hline Manuscript ID & IJGE-01-2021-0020.R2 \\
\hline Manuscript Type: & Research Paper \\
\hline Keywords: & $\begin{array}{l}\text { Economic empowerment, Disability, Women's entrepreneurship, } \\
\text { Microfinance, Vulnerable women }\end{array}$ \\
\hline \multicolumn{2}{|l}{} \\
\hline
\end{tabular}

\section{SCHOLARONE ${ }^{m}$ Manuscripts}


Empowering Vulnerable Microfinance Women Through Entrepreneurship:

\title{
Opportunities, Challenges and the Way Forward
}

\begin{abstract}
Purpose: This review explores how vulnerabilities arising from physical impairments, age, widowhood, forced displacement due to war or natural disasters, and sexual orientation affect women's microfinance related entrepreneurial activities and economic empowerment.

Design/methodology/approach: This paper is a structured literature review and uses PRISMA method. The paper also uses agency, resources, and achievement dimensions of empowerment to assess the findings.

Findings: Our review reveals that although microfinance services promote women entrepreneurship, they also exacerbate exclusion and further discrimination. Individual, household, institutional and community level structures shape women's agencies to access and utilise loans and conduct entrepreneurial activities; hence, ultimately economic empowerment. Originality: The originality of this paper arises from the conceptual model we synthesised from our review which illustrates how vulnerable women's agency is shaped by resources and how it affects their achievements in relation to entrepreneurial activities.
\end{abstract}

Key words: Economic empowerment, women entrepreneurship, microfinance, vulnerable women, disability, disaster

\section{Introduction}

In developing countries, promoting women's entrepreneurship through microfinance is 
recognised as a way to boost rural economies. Microfinance is the provision of financial services (e.g., loans, savings, insurance, and remittance), and sometimes nonfinancial services (e.g., skill development programs and business development support), to poor and low-income people with terms and conditions differing from mainstream financial services (Ledgerwood and Gibson, 2013). Institutions that provide microfinance services (microfinance institutions (MFIs)) often target women who start or operate businesses (women microfinance entrepreneurs). A key reason for targeting women is to integrate them into mainstream economic activities, move them out of poverty and/or empower them (Armendáriz and Morduch, 2010). However, certain groups of women are more vulnerable than others and often get excluded even from microfinance initiatives (Paprocki, 2016). Examples of such groups include people living with disability, widows, women-headed households, women of lower social classes or castes and ethnic minorities. These differing situations and circumstances shape women's experiences, perceptions and access to microfinance and ultimately their entrepreneurial actions (Banerjee and Jackson, 2016). Nonetheless, mainstream microfinance discourse has largely ignored how these vulnerabilities - considering only a limited number of issues such as household income or geographical locations - shape women's microfinance and entrepreneurship experience and ultimately economic empowerment.

This study, addressing the above research gap, answers the research question: How do vulnerabilities associated with physical impairments, age, widowhood, forced displacement due to war or natural disasters, and sexual orientation moderate the relationship between access to credit and economic empowerment? Drawing on gender and development studies literature (such as Paprocki, 2016; Kabeer, 2005; and Weber, 2016), we consider empowerment as a complex construct, consisting of economic, social and political dimensions. This paper, specifically, focuses on implications of microfinance for economic empowerment, in particular entrepreneurship. Using Kabeer's (2005) framework of agency, resources, and achievement, we 
assess available literature from an empowerment angle. We give particular attention to vulnerabilities arising from physical impairments, age, widowhood, forced displacement due to war or natural disasters, and sexual orientation and how these shape access to microfinance or entrepreneurship activities leading to empowerment or disempowerment.

Our critical analysis of the available literature demonstrates that individual, household, MFI and community level factors shape women's agencies to access and utilise loans and conduct entrepreneurial activities. We use these findings and contribute to theory by synthesising factors we identified into a conceptual model. Using this conceptual model, we contribute by outlining research and practical implications of economic empowerment for vulnerable women seeking microfinance services. We outline areas which require further academic research and contemplate whether microfinance initiatives should be radically reconceptualised to foster entrepreneurial activities which in turn could contribute to transformative changes in the lives of vulnerable women.

The rest of the paper is structured as follows: Section 2 explains the context for microfinance and women entrepreneurship, while section 3 outlines the theoretical framing. This is followed by the methods section (section 4). The next section (5), provides the critical review followed by the discussion section (6). Finally, the paper concludes with section 7, conclusion and way forward.

\section{Context: Microfinance and women entrepreneurship}

\subsection{Microfinance and its effects on women}

With the formal establishment of Grameen Bank by Dr. Muhammad Yunus in 1983 (Karim, 2011), development practitioners witnessed a rapid rise in microfinance schemes targeting poor and low-income people. Microfinance services provide credit, primarily targeting women who 
own and operate (or have the intention of owning and operating) businesses. The basic premise of microfinance is that economic poverty, and even social/political poverty, can be eliminated through providing access to finance for women. This gendered discourse, associated with community development narratives emphasise that women are underrepresented in employment or self-employment and through microfinance they can be integrated into the mainstream economy (Armendáriz and Morduch, 2010). Anecdotal evidence (e.g., case studies, videos, and success stories) highlight that at least some women fully or partially use microfinance for entrepreneurial purposes. Women use microfinance for business start-up and development purposes such as purchasing assets or stock, upgrading existing equipment, or paying for marketing (Mahmood, 2011; Tundui and Tundui, 2020). The opportunity for direct investment of loans in ventures also provide a platform for entrepreneurial learning (Sigalla and Carney, 2012).

However, the gendered premise upon which microfinance is promoted has been widely critiqued (Ali, 2014; Bateman, 2010; Maclean, 2017; Wilson, 2015). For example, the notion that women are the best poverty fighters has drawn criticism due to the 'triple burden' of gendered roles put squarely on women: productive, reproductive, and community labour (Maclean, 2017; Wilson, 2015). As feminist and development scholars highlight, those promoting microfinance too often gloss over its 'dark side'. Lenders, for example, often put intense pressure on borrowers to recover loans, leading to new forms of dominance over women (Wright, 2006). For instance, as joint liability, where a group is responsible for loan repayment, is designed to reduce institutional risk, it transfers the burden of loan repayment monitoring to borrowers (AlAzzam et al., 2012). This 'policing' of members by fellow borrowers damages existing social ties and networks within the community, such as by bringing shame to the family unit, or by putting strain on existing relationships within communities (Ghatak and Guinnane, 1999). Group members also tend to inflict penalties or non-financial sanctions upon each other, in case a 
member is unable to pay (Armendáriz and Morduch, 2010; Paprocki, 2016). These social and physiological pressures affect people's honour and dignity (Ali, 2014).

These issues are even more strenuous for women, as they are, as part of patriarchal societies, often considered traditional custodians of family honour. Hence, not being able to repay would be considered dishonourable (Wilson, 2015). As a result, women are more fearful of social sanctions and usually ensure loan repayments (Armendáriz and Morduch, 2010). Women are also often coerced by husbands and other family members to take out loans, causing them to bear the burden of loan repayments (Weber, 2016). In turn, women can face intense pressures from MFIs for loan repayments (Rahman, 1999). Rahman (1999) explains how a woman client, who was unable to tolerate such pressures, committed suicide. Problematically, in the microfinance context, staff performance measures are based on repayment rates. Repayment rates are also used as a basis of assessing women's empowerment, which supposedly provides evidence of women's economic independence. As a result, contemporary research questions the logic of considering women microfinance borrowers as both "vulnerable subjects and agents of economic change" (Khandelwal and Freeman, 2017, p. 49).

\subsection{Microfinance and women's economic empowerment}

Within gender and development studies literature, "women's empowerment is seen as much more than economic empowerment; it includes transformation of the power relations throughout society. The paradigm focuses on gender and class relations (and other social divisions) as a collective, rather than on women or men as individuals" (Drolet, 2010, p. 219). Nevertheless, mainstream microfinance theory and practice, as advanced by the World Bank, and associated bodies, promotes the idea that economic empowerment on its own can lead to "virtuous spirals" of "social" and "political" empowerment (Drolet, 2010, p. 216); hence, our focus on economic empowerment. 
Based on the above arguments, a key question to consider is whether or not microfinance is an effective tool for women's economic empowerment. Kabeer (2005) considers acquiring the ability to make choices, by those who have been denied choice, as empowerment. This ability to make choices relates to economic, social, political or many other dimensions. In this study, as entrepreneurship is directly linked to the economic dimension, we only explore economic empowerment. Furthermore, for the purpose of this study, we adapted Kabeer's (2005) definition into a microfinance-entrepreneurial context and define economic empowerment as women's ability to borrow microfinance loans, use loans for business start-up and development purposes and achieve outcomes that enhance their economic well-being.

The empirical evidence in microfinance reports both positive and negative effects on women's economic empowerment. The study of Pitt and Khandker (1998) is one of the very first to point out that women obtain far greater economic benefits through microfinance programs. Extending the original work, Khandker (2005) further explains that women seem to be more capable of increasing their non-land asset base in comparison to men. In addition, more recent studies, such as Li et al. (2011) and Murshid (2019), point-out that microfinance facilitates women's economic empowerment through providing greater control over their financial assets. Similarly by participating in microfinance initiatives, borrowers' ability to mitigate risks and cope with shocks improve in the long run; for example, Swain and Floro (2012) found that vulnerability associated with financial shocks declined for long-term members of self-help groups.

In contrast to the above outcome-based findings, process-based studies question the economic empowerment potential of microfinance. In many cases, although females borrow, loans are controlled by male members in the family (Goetz and Gupta, 1996). Wilson (2015) reiterates this and points out that power relations within the household in a patriarchal society 
play a key role in financial control. Loans granted to women are usually invested in productive assets which they do not have control over (Garikipati, 2008). Therefore, as long as these patriarchal power relations remain unchallenged access to credit on its own (Garikipati, 2008), devoid of social and political contexts, would not lead to women's empowerment (Maclean, 2017). Hence, contrastingly, these studies assess economic empowerment potentials by assessing women's embeddedness within patriarchal social forces, viewing women as "empowered citizens", as opposed to simply "rational economic women" capable of pulling "themselves up by the bootstraps" (Tanima et al., 2020, p. 16).

Another issue is the role of microfinance on entrepreneurship development. Academics such as, Alawattage et al. (2019), Karim, (2011) and Weber, (2016) argue that 'enterprises' financed by microcredit typically have no potential to scale up or access formal commercial institutional funding; hence, these individuals are not entrepreneurs in the full sense, and are referred to as "perpetual entrepreneurs-in-waiting" (Alawattage et al., 2019, p. 55). Pearlman's (2012) argument on vulnerability, associated with income risk, driving entrepreneurs to reject high risk but high yielding opportunities, could be the reason for lack of microfinance driven enterprise growth.

\subsection{Vulnerabilities beyond poverty}

Microfinance borrowers, particularly women, often remain underpinned in various forms of vulnerabilities, as they are poor, live in rural areas, have limited access to services or belong to a lower caste or class. The available evidence, however, demonstrates that poor, rural, lower caste or class women struggle when accessing and utilising microfinance for business purposes. This can be due to both institutional and client-related factors. The poorest women, for example, are considered too risk averse to borrow and invest by both group members and MFI staff 
(Coleman, 2006; Hermes and Lensink, 2011). Similarly, microfinance delivery models related to loan sizes and repayment frequency often end up excluding poorer clients (Coleman, 2006; Hermes and Lensink, 2011). As a result, women often opt for low-risk ventures (Dutta and Banerjee, 2018) or are forced to follow less risky livelihood activities, traditionally considered 'female productive roles' such as tailoring and rearing domestic animals like chickens and goats (Dutta and Banerjee, 2018). This may lead to increased levels of indebtedness, debt spirals, and erosion of social capital amongst the vulnerable (Banerjee and Jackson, 2016).

Loan decisions are also affected by stereotyping associated with borrowers' personal characteristics (Corsi and De Angelis, 2017). Guérin et al. (2015) found that lower caste people have a significantly poorer chance of starting a business. The businesses they do start are smaller, less profitable and based in very specific sectors. This is found to be due to caste and gender based social practices shaping who can produce what, to whom and at what price.

In addition to poverty, geographical locations, and class or caste, vulnerabilities arising from physical impairments, age, widowhood, forced displacement due to war or natural disasters, and sexual orientation could shape women's microfinance and entrepreneurial experiences. However, the available research evidence is dispersed, where these issues are not comprehensively or systematically analysed to identify contemporary research or policy implications. In this paper, we aim to address this research gap and assess evidence from an empowerment based theoretical angle.

\section{Theoretical framing: Agency, resources, and achievement}

Kabeer's (2005) conceptualisation of empowerment includes three closely interrelated dimensions: agency, resources, and achievements. Agency represents the processes by which choices are made and put into effect and have both positive and negative connotations. The 
positive notion of agency reflects people's ability to make and act on their own life choices, even in the face of others' opposition (Kabeer, 2005). This is also known as 'power to' act (Kabeer, 1999). The negative connotation of agency is the capacity of some actors to override the agency of others (Kabeer, 2005). This is known as 'power over' others (Kabeer, 1999). Power is also significant in the absence of agency where institutional biases, and cultural or ideological norms constrain people's ability to make choices (Kabeer, 2005). Therefore, agency within the context of economic empowerment implies the ability to actively exercise choices while challenging the power relations.

Resources are the medium through which agency is exercised. This includes economic, social, human, or any other resources that enhance women's abilities to exercise choices (Kabeer, 1999). In institutional contexts (e.g. organisations, households, and communities), certain actors have privileged positions over others concerning how rules, norms, and conventions are interpreted (Kabeer, 2005). This privileged position allows them to govern and determine resource allocation and make exchanges according to their own rules and norms (Kabeer, 1999). The way in which resources are distributed thus depends on the ability to define priorities and enforce claims (Kabeer, 2005).

Achievements refer to the outcomes of agency (Kabeer, 2005). That is, resources and agency make up people's capabilities (Kabeer, 1999). In relation to empowerment, achievements have been considered in terms of both the agency exercised and its consequences (Kabeer, 1999). For example, women's increased self-confidence leading to new business opportunities can be considered a pathway for empowerment.

\section{Method}

We considered a systematic literature review as an appropriate technique to answer the 
research question as it is a rigorous, transparent and reproducible way to make sense of studies in a particular research area (Tranfield et al., 2003). The systematic review was guided by transparency, clarity, focus, equality, accessibility, broad coverage, and synthesis principles (Thorpe et al., 2005). We used PRISMA process and the checklist items highlighted by Moher et al. (2009) in structuring, collecting relevant papers, and reporting the findings. We followed the identification, screening, eligibility and inclusion (Moher et al., 2009) criteria when finalising the journal articles used in this study.

As we were interested in different categories of vulnerable women, we used specific terms (or synonyms of the terms) to identify key literature. We first searched for the key term 'microfinance', coupled with 'entrep*' and specific categories of vulnerabilities. We used search terms: a) 'disabled' 'disability' 'disab*'; b) 'widow*' 'single-headed'; c) 'older' 'younger' 'aged' 'youth'; d) 'Transgender' 'lesbian' 'gay'; e) 'disaster'; and f) 'refugee'. These terms were identified from the general literature on disadvantaged or vulnerable groups. This resulted in a very limited number of articles. Hence, we decided to be broader in our article search by omitting 'entrep*'. However, to be comprehensive we searched for the word combination 'vulnerable' and 'microfinance' or 'microcredit' and 'microfinance' or 'microcredit', with 'entrep*'. Then we verified whether specific vulnerable groups mentioned above are reflected in the articles and included new articles into our list. We also searched for articles using 'micro savings' and 'micro insurance' to capture any microfinance initiatives which go beyond credit.

Our search was focused on the databases Scopus and EBSCOhost. We searched for the above mentioned terms in key words, titles and abstracts of journal articles published during the period 2000 to 2020 . This helped us to identify an initial list of articles with the search terms. Then one of the authors read the abstracts of all the journal articles and identified the most relevant ones. The main inclusion criteria used was whether the journal article's focus was on 
individuals. We removed duplicate articles from our original list and selected articles for which we had the full access.

There were 491 articles on the initial list and after the screening process the final list contained 28 highly relevant articles. Out of these 28 articles, 16 were related to microfinance and disability and all other categories had a very limited number of articles. Hence, we looked at the references of these 28 articles and journal articles which cited these 28 articles and selected relevant articles which corresponded to our time period and research focus. This process helped us to identify an additional eight journal articles which aligned with our research focus (see online supplementary for key findings of these papers).

This final set of 36 articles were then categorised into different groups according to vulnerabilities. We prepared an excel spreadsheet with journal article details (abstract, citation count, journal name, authors, year of publication), type of paper (e.g., conceptual, empirical, literature review, other), theoretical/conceptual foundation used in the paper, key findings, and whether the article discussed key findings exclusively for women. We then used the key themes emerging from these studies and looked at them through an empowerment angle to identify the role of agency, resources, and achievement.

\section{Review: Vulnerable microfinance entrepreneurs}

\subsection{Overview of results}

\section{a) Number of articles and authors}

Overall, out of the 36 articles, the highest number of articles (21) were related to microfinance and disability. The second highest number of papers were in the category natural disasters and climate change risk ( 7 articles). Other categories had a very limited number of articles (see Table 
1). We also did not find any articles related to older women or gay or lesbian people and their access and use of microfinance services.

Insert Table 1 about here

Even within these articles, exclusive focus on women was very limited. For example, within the disability and microfinance category, only two articles (i.e. Chaudhry (2016) and Lewis (2004)) discussed findings exclusively for women while three articles in the natural disasters or climate change risk category were exclusively focused on women (i.e., Kayser et al. (2010), RayBennett (2010) and ul Haque et al. (2019)). The two exceptions were the widows or femaleheaded households and cisgender/transgender categories. This is due to the nature of the search terms we used such as widow or female-headed; hence, all papers in this category were fully or partially related to women. In the remaining articles, gender was a key variable or a dummy variable in the analysis, or the effects on women were assumed to be similar to men and presented without segregating according to gender.

Within our review, the reason for the higher number of articles related to people with disabilities is due to the work of two researchers: Beisland and Mersland (see Table 2). They coauthored four papers together $(2012,2014 a, 2014 b, 2017)$ and two papers with other authors (Beisland, D'Espallier and Mersland, 2019; Beisland, Mersland and Zamore, 2016). Mersland has two additional papers co-authored with other researchers (Labie, Méon, Mersland and Szafarz, 2015; Mersland, Bwire and Mukasa, 2009). Furthermore, Sarker also published two articles related to people with disabilities and microfinance $(2013,2020)$.

The literature generally lacks publications on these other vulnerabilities. In the other vulnerability categories, with the exception of youth, there is no clear author profile. Within the youth and microfinance category, Flynn and Sumberg have two publications on youth savings 
groups $(2017,2018)$.

\section{b) Details of the articles (sources, types of study, countries, and theory/conceptual focus)}

The articles we selected were published in a variety of journals focused on development, disasters, health and medicine, social sciences, economics and finance or business (see Table 2). We also noticed that there was a very limited number of 'entrepreneurship-oriented' journals available for our review.

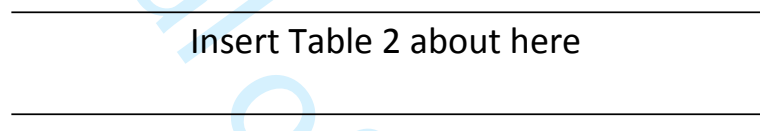

As Table 2 shows, most of the articles in our review were empirical studies, with five qualitative studies and two mixed method studies. Other studies were mainly quantitative in nature. These empirical studies were mainly conducted in Africa (i.e., Tanzania, Burkina Faso, Uganda, Zambia, Zimbabwe and Ghana), Asia (i.e., India, Afghanistan, Bangladesh, Pakistan, Nepal, Cambodia and Malaysia) or South America (i.e., Colombia, Ecuador). These geographical foci are to be expected given the prominence in microfinance in these regions.

There was also a general lack of theoretical framing within these articles. The studies within the disability category were mainly framed with the concepts of 'exclusion' from microfinance services or 'discrimination' of vulnerable clients by staff or institutions. Studies in other categories were framed around empowerment, financial inclusion, climate change, risk and disaster recovery. The two exceptions with clear theoretical basis were Acheampong (2018), which used resource-based theory and gender theory, and ul Haque et al. (2019) which used Mayoux's Feminist empowerment theory and relational theory of risk. 


\section{c) Number of articles and citations by year of publication}

We also collected data related to the year the article was published and Google scholar citations related to each of the articles (see Figure 1 for a summary). From this data, we noticed that before 2008 , there were only two articles in total, after which there was at least one article per year.

We also found that nine articles were widely cited with more than 30 citations each. Out of these widely cited articles, Hammill et al.'s (2008) work was the highest with 126 citations. Followed by Lewis's (2004) article which had 70 citations, Parvin and Shaw's (2013) article with 49 citations and Beisland et al.'s (2019) article with 42 citations.

Insert Figure 1 about here

\subsection{Key themes emerging from the articles}

In this section we report on the key themes emerging from the systematic review. In particular, we explain key findings identified from the articles under each theme and, wherever available, the findings specific to women. In each of the sections, aligning with our focus, we also show how Kabeer's (2005) agency, resources, and achievement aspects are emerging from these findings.

\section{a) Disability}

\section{Use (or non-use) of microfinance by disabled people or their caregivers for entrepreneurship:}

Reflecting power to act, the evidence suggests that people with disabilities use microfinance loans for business purposes (Beisland and Mersland, 2012). There are no significant differences 
in motivations for business start-up between persons with and without disabilities (Beisland et al., 2016). MFIs lend to disabled people, as long as the savings and other requirements are fulfilled; hence, Beisland and Mersland (2017) and Nuwagaba et al. (2012) explain disability per se does not hinder disabled people's access to microfinance services. However, even among the MFIs that lend to people with disabilities, although disability prevalence is generally higher among the female population, Beisland and Mersland (2017) found that the borrower statistics do not reflect the overall population data. Hence, literature in this category point out women with disabilities are considered more financially disadvantaged than males with disabilities (Beisland and Mersland, 2017; Lewis, 2004).

Studies also show that it is more common among disabled people to start ventures with their own money or family money and then obtain money from MFls later for business development purposes (Beisland and Mersland, 2012). The ability to start a business and earn money helps women, specifically when they perceive marriage is not a possibility due to their disability (Chaudhry, 2016). These studies show peoples' agency and power to act. Thus, people with disabilities are considered an untapped market for microfinance services (Beisland and Mersland, 2014a; Mersland et al., 2009; Sarker, 2013).

Chaudhry (2016), using a critical disability feminist perspective, reports why disabled women are apprehensive about taking loans to invest in new enterprises. The author, using an ethnographic study, reveals that women with disabilities are disadvantaged in other ways including by caste, class, impairment type, and not having familial/kinship support. Due to these additional disadvantages, disabled women in comparison to nondisabled women are not able to perform productive roles in the domestic spheres, or be mobile in local markets for entrepreneurial tasks. This, coupled with limited non-farm sector opportunities in general, and even fewer for people with disabilities, makes disabled women more apprehensive to accessing 
microfinance services.

Disabled microfinance clients, compared to others, have a high tendency to save (Beisland and Mersland, 2017) where women more frequently become members of savings groups than men (Beisland and Mersland, 2012). In some contexts, savings help them to develop some security (e.g., buy gold to secure their future) and they tend not to risk their life savings by investing in an enterprise where success is uncertain (Chaudhry, 2016). These decisions women make reflect power to act; people's ability to make and act on their own life choices. At the same time, these studies reinforce the need for services other than loans; that is, resources required to exercise agency.

Alongside financial services, the literature identifies the need for other interventions to develop capacities of people (not just of women) with disabilities. These include skill development and financial literacy training programs (Sarker, 2013). In some situations, training programs on self-care are important even more than livelihood support (Polu et al., 2015). These studies (i.e., Heeren et al., 2014 Polu et al., 2015), nevertheless, indicate the need for these interventions to be conducted hand-in-hand with socio-economic rehabilitation programs.

Within households, having a disabled family member can give shape to caregivers' selfemployment/employment roles. As the majority of the caregivers are women, the task of caregiving takes up a significant proportion of their time (Nair et al., 2018). Although selfemployment is considered a much better prospect for caregivers, the long-term nature of the illness and disability could have added financial burden, the outcome of which could be continued poverty (Nair et al., 2018). Hence, MFIs have a social obligation to facilitate agency that is 'transformative' for disabled people and their caregivers.

Challenges and barriers faced by disabled people in accessing microfinance for 
entrepreneurship: Most studies in this area suggest that disabled people face challenges when accessing loans due to institutional norms and the existence of differing societal and community actors. At the individual level, women with disabilities have obstacles similar to women in general who access loans (e.g., lack of collateral, fewer resources to business, lack of experience or training programs). In addition to these general obstacles, disability shapes their experience, altering and intensifying these obstacles and adding others (Lewis, 2004). These are linked to agency, resources, and achievement aspects of women's empowerment.

The exclusion of people with disability, as per available literature, occurs from low selfesteem of disabled people themselves, exclusion by other members, exclusion by staff, and exclusion by service design (Mersland et al., 2009). Low self-esteem, which leads to selfexclusion, occurs due to repeated negative experiences (Mersland et al., 2009). For example, people with disabilities are usually considered as 'bad risks' for financial agencies and considered inappropriate for microcredit or business services; hence, they are often referred to rehabilitation or charitable programs (Lewis, 2004). Furthermore, people with visual and hearing impairment are more constrained than those with physical impairments as they have a hard time following the discussions due to not having appropriate support (e.g., Braille, sign language) (Nuwagaba et al., 2012). Attitudes such as microfinance is not for people with disabilities also limit the access (Nuwagaba et al., 2012). These negative discourse and societal norms (which have 'power over' women) lead to loss of self-confidence and hinder women's decision-making capabilities.

Solidarity groups present platforms where certain groups of people have power over certain others (Chaudhry, 2016). This leads to exclusion by members, in particular the most vulnerable. For example, due to self-selection bias, group members decide who gets into the groups (Mersland et al., 2009). The stigmatisation and perceived risk associated with disabilities 
further worsen the self-selection bias. Stigma related issues also causes discrimination regarding access to training programs (Lewis, 2004).

Exclusion by staff, due to conscious or unconscious biases, affects their assessment of credit worthiness and subsequently the entrepreneurial process. Reflecting 'power over' others, evidence suggests that experienced loan officers perceive people with disabilities as high credit risks and, hence, neglect more vulnerable clients (Beisland et al., 2019; Beisland and Mersland, 2014b; Labie et al., 2015; Sarker, 2020). The rejection happens due to both prejudice and 'statistical discrimination' where staff members use an individuals' disability as an indication of their entrepreneurial potential (Sarker, 2020). This could also be partly due to late payments; as late payments are found to be higher among disabled clients (Beisland and Mersland, 2017). Beisland and Mersland (2017) emphasise that reasons for these late payments could be because of having additional health related expenses, not having enough money to make the repayment, MFIs providing standard loan products for people with disabilities, or a combination of any of these factors. To mitigate some of these staff related exclusions, Sarker (2013) recommends recruitment of disability friendly staff, having training programs around these issues, and implementing policies outlining services for disabled people. Building strategic partnerships with organisations that support disabled people is also recommended (Sarker, 2013).

Exclusion by design happens due to the microfinance loan terms and conditions such as compulsory savings requirements or weekly/monthly meetings. A key microfinance practice is the requirement for solidarity groups to meet weekly/monthly at a group member's house in the presence of a staff member. The primary function of this meeting is for the staff member to collect repayments. These meeting platforms are less accessible for people with disabilities for reasons such as physical location of the meeting, and lack of appropriate transport services (Lewis, 2004). Informational barriers, due to communication barriers (e.g., verbal or written 
form of information provided), can also exclude people from microfinance services (Lewis, 2004; Nuwagaba et al., 2012).

Furthermore, systematic failures or physical or informational barriers contribute to long term exclusion of women with disabilities from MFIs. Girls with disabilities are frequently the last of families' priorities to be provided with education which has long-term impacts on accessibility to financial services (Lewis, 2004). Loan officers, for example, perceive women with disabilities as unable to understand information or manage finances (Lewis, 2004). All these factors can hinder the participation of disabled women in economic activities, entrepreneurial investments, and their entrepreneurial actions.

Use of microfinance for rehabilitation leading to entrepreneurship: One less common theme identified from literature is the role of microfinance in post-rehabilitation efforts in poor and war-torn areas (Daher and Flessa, 2010; Fiasse, 2011). These services are relevant for both men and women and reflect the agency to make decisions on their microfinance use. Due to low income or lack of basic welfare systems, patients who suffer from a walking disability or chronic lung diseases find it difficult to finance necessary healthcare equipment such as wheelchairs or oxygen concentrators (Daher and Flessa, 2010). This acts as a barrier for them to engage in income generation tasks. Hence, Daher and Flessa (2010) state that microfinance has the potential as a tool for financing medical devices.

\section{b) Women affected from natural disasters or climate change risks}

Use of microfinance for disaster risk reduction and recovery: Reflecting achievements, i.e., outcomes of agency, microfinance (credit, savings, and insurance) contributes to management of financial, social, natural, human, and physical resources and these help in climate change 
adaption and disaster risk reduction, response and even recovery (Hammill et al., 2008 Parvin and Shaw, 2013). However, these services need to be matched according to the requirements of different client groups; this is because of the differences in resources, the medium through which agency is exercised. For example, economically vulnerable people prefer savings and insurance for climate change adaption rather than credit. In contrast, insurance and credit services are much preferred by economically secured clients (Hammill et al., 2009). Similarly, within disaster-prone areas credit needs to be integrated with other disaster mitigation measures (Hammill et al., 2008).

For women, natural disasters have a significant impact on their micro-enterprise sustainability (ul Haque et al., 2019). Microcredit services are useful to replace women's livelihood assets that have been lost in disasters (Ray-Bennett, 2010). These loans should be large enough to meet the needs of the women post natural disasters and at the same time should not be too large to be burdensome for women with limited resources (Kayser et al., 2010). Nevertheless, inefficient microcredit delivery has found to exacerbate caste, class and gender inequalities (Ray-Bennett, 2010).

Use of insurance to manage risks: Another way of mitigating adverse climate effects on livelihoods is through crop insurance (Bauchet et al., 2017; Kazianga and Wahhaj, 2020). A rainfall indexed insurance pilot project, with migrants to the capital of Burkina Faso, who insured their rural family members engaged in farming, contributed to an increased uptake of insurance products. This demonstrates that rainfall indexed insurance can complement informal risk sharing networks (Kazianga and Wahhaj, 2020). Voluntary bundling of insurance products with credit is also considered as an opportunity to enhance insurance uptake (Bauchet et al., 2017). These strategies facilitate resources that enhance people's (including women's) abilities to 
exercise choices.

\section{c) Youth and younger women}

Role of savings groups/savings and loan associations in financial inclusion: Savings groups and schemes are considered one of the effective mechanisms of financial inclusion for young people when reducing household vulnerabilities (Flynn and Sumberg, 2017; Lowicki-Zucca et al., 2014). Savings groups facilitate young people's agency to act, through providing access to loans, based on savings, or management of operational expenses and cash flow of members' microenterprises (Flynn and Sumberg, 2018). The engagement of savings groups is an embedded activity in family and immediate social networks (Flynn and Sumberg, 2017).

Among women, many save money given to them by their family members (i.e., husbands, partners, parents and guardians) and the entrepreneurial financial management activities are done by sharing, cooperation, joint action, and co-investment (Flynn and Sumberg, 2017). However, Flynn and Sumberg (2017) report that few women did not inform their spouses about their savings or investment activities, which could imply that women prefer to keep their savings for an emergency.

\section{d) Widows or female-headed households}

\section{Decision making and entrepreneurial behaviour differences between female-headed and}

male-headed households: Having access to microfinance removes barriers for financial resources in entrepreneurial activities and provide opportunities to enhance decision making (Acheampong, 2018; Theophilus and Paul, 2019); that is, it provides power to act. It also has the potential to make women more economically active and enhance overall decision making 
(Theophilus and Paul, 2019). Expanding on these findings further, Acheampong (2018) found that female led families are more likely to have better returns to microfinance than their male counterparts. This is due to women who generally have the capacity to manage the businesses opting to use microfinance services, which is then reflected in business returns (Acheampong, 2018).

\section{Contextual factors that shape livelihood activities of widows/female-headed households:} Chaudhry's (2016) ethnographic account is one of the key papers in our review which outlines how livelihood tasks affect widows and single women. Women in Chaudhry's (2016) study were also disabled and show how context related factors further intensify their livelihood experiences. Similarly, Ray-Bennett (2010) and Kayser et al. (2010) explain social factors that shape widows, single or abandoned women's livelihood recovery after natural disasters. Although these papers highlight the usefulness of microfinance for livelihood activities, these studies also emphasize that effectiveness of microfinance depends on social or contextual factors such as caste or class hierarchies (power over other women) (Chaudhry, 2016; RayBennett, 2010; Kayser et al., 2010). Inefficient microcredit delivery can re-intensify these local gender and class hierarchies in post natural disaster situations (Ray-Bennett, 2010).

\section{e) Refugees}

Rebuilding livelihoods through microfinance: Only two articles included in our study are of refugees using microfinance services. These articles are not specific to women. Idris (2019) found that microenterprise support programs help resettled refugees to start businesses such as restaurants, grocery shops, coffee shops and taxicabs. These businesses also serve as spaces for newly resettled refugees to integrate and engage. Similarly, Colgan and Kolínský (2014) 
explain a program run in a Bhutanese refugee camp in Nepal which encompassed four types of key activities: self-reliance, vocational training, social awareness building, and loan provision. Colgan and Kolínský (2014) also suggest that MFIs may have to tailor their programs and be innovative in addressing legal and other issues arising from 'statelessness'. Hence, these articles reveal that refugees who use microfinance and entrepreneurial support, exercise agency and create jobs for themselves, their families, and for others in their communities.

\section{f) Cisgender and transgender woman}

Intention of starting a business with microfinance: Lall et al.'s (2017) study provide some insights into cisgender and transgender communities and their intentions in starting a business. Lall et al. (2017) report that cisgender and transgender woman sex workers, as a part of microfinance based HIV prevention intervention, are interested in starting businesses. Many are involved in the sex industry due to lack of employment options, which illustrates actions taken when there is lack of choices. Lall et al. (2017) also found that training programs and financial literacy sessions, and not just credit, need to be part of the package to ensure a smooth transition to self-employment. However, perceived transphobia, stigma, and lack of resources are cited as barriers for self-employment (Lall et al., 2017).

\section{Discussion and future research}

Using a systematic literature review, this study assessed the research question of How do vulnerabilities (i.e., physical impairments, age, widowhood, forced displacement due to war or natural disasters, and sexual orientation) moderate the relationship between access to credit and economic empowerment? In this section, we first discuss implications derived from the 
overview of results and second, the implications derived from our findings by drawing on Kabeer's $(1999,2005)$ empowerment framework.

\section{Implications derived from the overview of results}

Our overview of the results highlights that available studies are highly concentrated on microfinance and disability. Although studies are emerging related to other vulnerable groups (e.g., refugees, transgender people, and youth), there seems to be limited focus beyond mainstream microfinance borrowers and the role microfinance services could play to enhance livelihood activities. The key themes identified in this review, across the different vulnerable groups suggest that studies have so far focused on: a) use (or non-use) and patterns of microfinance use for livelihood activities; $b$ ) challenges and barriers faced by people in accessing microfinance; and c) effects of microfinance beyond livelihood related activities. However, these studies have a very limited entrepreneurial focus. This indicates an opportunity for entrepreneurial scholars to look at vulnerable groups further and study whether there is any role of microfinance in promoting entrepreneurship and reducing vulnerabilities.

Our findings also indicate that studies exclusively focused on women are very limited. We contemplate the reasons for such limited number of studies, specifically in the area of younger or older women or widows/female-headed households. As indicated by our analysis, we believe this is due to empirical studies considering these factors as just another variable. Not separating gender effect, however, seems to overshadow the effects and experiences of vulnerable women, and other complexities associated with their vulnerabilities in accessing microfinance services, and starting or developing businesses. For example, the few studies available exclusively on women (i.e. Chaudhry, 2016; Lewis, 2004; Kayser et al., 2010; RayBennett, 2010; ul Haque et al., 2019) in our review, clearly demonstrate how context and other 
complexities shape vulnerable women's experiences. Hence, we advocate for more studies focused on women.

Another key insight from our review is the lack of theoretical grounding of available studies. Available studies are mostly framed around discrimination or exclusion, empowerment, financial inclusion, climate change, and risk and disaster recovery. These papers very rarely drew on well-established theories in demonstrating empirical insights. We see this as an opportunity for future studies to tap into, in order to provide unique insights. Similarly, while there are a few qualitative studies in this area, these studies did not take a 'theoretical leap' and develop theories or conceptual frameworks that can be tested and validated in the future. Hence, we see the need for theory-oriented qualitative studies and encourage researchers to advance scholarship in this area.

We also encourage researchers to assess the same issue from different theoretical and methodological perspectives and move beyond existing ontological and epistemological frames. The existing studies have a limited variety in ontological, epistemological and methodological framing and this could affect assessing microfinance and vulnerable people from a critical perspective. For example, consider the role of social relationships in microfinance. From an accountability angle, at the level of interpersonal relationships, Alawattage et al. (2019) critique the commercialisation of social relationships by MFIs. They point-out that MFIs harness the interpersonal village level social relationships for institutional profits. From an empowerment angle, Hulme (2004) is critical of the notion of considering social capital at the village level, on its own (without close analysis of broader social factors), as favourable. The author points out that civil action and social relationships can also keep poor women in a perpetual cycle of poverty. Similarly, looking at vulnerabilities associated with women microfinance borrowers from different theoretical perspectives could provide in-depth and critical insights. 
In addition, we identify the need for studies from various geographies. There is very limited variability in literature in relation to geography, types of microfinance services or service delivery models. Furthermore, there are very few cross-country studies. As the social protection mechanisms and entrepreneurial ecosystems differ from country to country, we see the need for more studies in these areas.

\section{Implications on empowerment through entrepreneurship}

From Kabeer's $(1999,2005)$ conceptualisation of empowerment, the themes and key findings in our review could be synthesised into a process model outlining a pathway of economic empowerment (see Figure 2).

Insert Figure 2 about here

As Figure 2 illustrates, MFIs, due to their social objectives, aim to provide financial services to vulnerable women (e.g., disabled, youth, and female-headed families) to facilitate their entrepreneurial achievements. As we found from this review, women access financial services such as credit, insurance and savings and exercise their agency. However, women who are not experiencing any vulnerabilities could become vulnerable due to contextual changes or life cycle events and that can affect their entrepreneurial decisions and activities. The review points out some examples for such events: disability, war, and natural disaster. Hence, power to act and exercise their agency by starting or developing businesses could change after such shocks, as women might become more vulnerable with such events.

Women's agency is central to the access and utilisation of microfinance loans and achieving entrepreneurial outcomes. However, as identified in our review, individual, 
household, MFI and community level factors impact the way women make decisions and choices. These factors affect women's agency by shaping 'power to' or 'power over' women. The effects of some of these factors are not straight forward and could be complex. For example, as our review demonstrates, experienced loan officers are more concerned about credit risk and effective use of their time when serving disabled people (Beisland et al., 2019; Beisland and Mersland, 2014b). Similarly, the review highlights that conventions, rules and norms at community level lead to further exclusion and discrimination of vulnerable women when accessing and utilising loans.

Resources illustrated in Figure 2 shape both 'power to' and 'power over' women's entrepreneurial decisions. These factors also determine whether women exercise a passive or active form of agency. Among vulnerable women, agency seems to be more passive where they are required to take actions in situations consisting of limited numbers of choices. As vulnerable women have limited numbers of choices, they seem to be trapped within a vicious cycle of loans.

As Figure 2 illustrates achievements within the microfinance entrepreneurial context is the degree to which entrepreneurial potential is realised. We identified that some women, although vulnerable due to physical impairment, statelessness, age or sexual orientation, use or intend to use microfinance services to start, modify or develop businesses. However, as our review demonstrates, constraints and hindrances which some vulnerable women face, make it near impossible for them to effectively use microfinance services for business purposes.

To mitigate some of the resource constraints and achieve entrepreneurial outcomes, transformative actions are required (see Figure 2). Our review suggests that in order for microfinance initiatives to bring about transformative changes, structural barriers, such as household, institutional and community norms, rules, conventions and structures, must be challenged. Microfinance programs must be adjusted for the specific needs of the communities 
(Mersland et al., 2009) or combined with other rehabilitation or development initiatives. For example, Lewis (2004, p. 36) recommends "building bridges", rather than constructing completely new programs from scratch. In addition, in order to encourage inclusion, programs must be put in place to transform perceptions of differing groups such as loan officers, solidarity groups, and wider members of the community (Mersland et al., 2009). In particular, Saker (2013, 2020) emphasises having policies and practices in place to mitigate exclusion by staff or design and staff capacity building to minimise unconscious biases.

The above three empowerment areas (i.e., agency, resources, and achievement) and lack of literature related to vulnerabilities beyond poverty, emphasise that researchers need to have a closer look at these areas in future. Table 3 summarises some future research that could be undertaken to understand these vulnerable groups of women.

Insert Table 3 about here

As Table 3 shows, current research does not illustrate the ways in which different vulnerable groups, except disabled, exercise agency and use resources to achieve entrepreneurial outcomes. For example, we did not find any articles related to older women's use of microfinance services. Anecdotal evidence such as the financial diaries of Collins et al. (2009) however, Illustrates that older women borrow money to accumulate assets to ensure that they have some 'nest eggs' for retirement. Similarly, aging effects are different for women and it affects their entrepreneurial behaviour (Lévesque and Minniti, 2006). Hence greater clarity is required on usage of microfinance loans by older women and whether insurance could mitigate some of these old-age concerns (rather than engaging in entrepreneurial activities). As noted, the available studies do not highlight how technology and emergent economic activities 
shape women's agency, resources and achievement. For example, young people often use mobile money accounts (Anderson et al., 2019), which aligns with the fact that they increasingly find work in the gig economy. In order to enhance economic empowerment, these trends and patterns need to be better understood.

We also see the need to study the role of life cycle and contextual shocks and how it affects women's agency, use of microfinance services and entrepreneurial outcomes. In particular, we see the need for qualitative and quantitative studies or use of panel data sets in identifying the shocks, and how these shocks affect women's decisions and entrepreneurial activities. These effects could vary depending on their access to relief, social or health support, credit, and savings and insurance services. In addition, qualitative in-depth studies could highlight nuances associated with women's decisions to use microfinance services, and their resilience and adaptability during these shocks which make families vulnerable.

The current COVID-19 pandemic and challenges associated with the global health crisis further intensify the contextual and life cycle shocks vulnerable groups of people experience. The pre-existing malnutrition situations and disruptions in household income have made it hard for vulnerable women to cope during the pandemic (Brickell et al., 2020). At the same time, the evidence illustrates that, in some countries, microfinance borrowing has been used to cope with gaps in public service provisioning during lockdown periods (Brickell et al., 2020). However, this should be a source of concern as taking out money could lead to over-indebtedness, leaving the poor more vulnerable (Brickell et al., 2020). Therefore, the way vulnerable women use microfinance and exercise agency could differ during the pandemic; hence, how people cope and manage their livelihoods during this time needs to be further studied.

Under the resources dimension of empowerment, we see the need to extend our findings further. In particular, we see the need for future studies to explore the mediating and 
moderating role of individual, household, MFI and community factors on access or utilisation of microfinance. Factors such as policy level changes, COVID-19 support and institutional policies, staff training programs, and product modifications, also require further exploration. Action research programs could be particularly useful here.

Finally under achievement, we see the need to study entrepreneurial intentions, actions and self-efficacy. In particular, individual, household, MFI and community level factors require further examination. Specifically, during the COVID-19 pandemic how health related concerns shape entrepreneurial tasks, such as digitalization and use of social media need to be further studied.

\section{Conclusion}

As evidenced in this study, 'business as usual' is not enough for empowering vulnerable women and promoting entrepreneurship. This review indicates that women, in terms of vulnerabilities, are a diverse group. The structural barriers, social norms, and rules shape vulnerable women's experiences in accessing microfinance, utilising loans for business start-up and in developing or up-skilling themselves. Using these findings this study contributes by synthesising a conceptual model and demonstrates conceptual links between contextual and life cycle events, women's agency of accessing and utilising microfinance, resources that shape women's agency and the extent to which entrepreneurial potential is realised or failed to be realised.

Using this conceptual model, this review contributes and highlights the need to question underlying assumptions and institutionally embedded practices of MFIs, specifically in relation to vulnerable groups. This includes looking at the delivery models, terms and conditions, nonfinancial support mechanisms, and the operationalisation mechanisms at the ground level. It is also worth evaluating whether institutional practices have unintended consequences on 
vulnerable women groups. In this regard, the implications of capitalism, regarding feminisation of credit, need to be carefully considered to understand vulnerable women's agencies to make choices and business decisions.

These findings also led us to contemplate whether alternative business approaches or transformative actions are required for MFIs to achieve social outcomes. Designing a mixed mode of delivery could be a suitable option, for example, a graduation model for victims of natural disasters, mobile money for youth, or individual customised loans rather than group loans for persons with disabilities. The alternatives could also focus on outcomes or impacts of loans (e.g., number of businesses started by vulnerable women), and processes (e.g. assessing the progress of such businesses), rather than just input measures (e.g., number of loans disbursed). In addition, rather than focusing on repayment rates, there could be a composite measure.

Finally, we also recommend future studies to go beyond the MFI level into individual, household or community levels and use multiple methods and paradigms to study the role of microfinance among vulnerable women. Without knowing the individual, household or community dynamics, effective financial or capacity building programs cannot be developed for vulnerable women microfinance entrepreneurs. This aligns with Welter's (2011) work on contextual-embedded practices and looking at contextual practices from historical, institutional, temporal, spatial or political angles. These contextual embedded studies could assist policymakers and social support services to understand issues and allocate resources more effectively. 


\section{References:}

Acheampong, G. (2018), "Microfinance, gender and entrepreneurial behaviour of families in Ghana", Journal of Family Business Management, Vol. 8 No. 1, pp. 38-57.

Al-Azzam, M., Carter Hill, R. and Sarangi, S. (2012), "Repayment performance in group lending: Evidence from Jordan", Journal of Development Economics, Vol. 97 No. 2, pp. 404-414.

Alawattage, C., Graham, C. and Wickramasinghe, D. (2019), "Microaccountability and biopolitics: Microfinance in a Sri Lankan village", Accounting, Organizations and Society, Vol. 72, pp. 38-60.

Ali, H.M.A. (2014), "Blaming the poor and legitimizing coercive loan recovery strategies: Unveiling the dark side of NGO practices in Bangladesh", Anthropologica, Vol. 56 No. 1, pp. 177-191.

Anderson, J., Hopkins, D. and Valenzuela, M. (2019), "The role of financial services in youth education and employment", CGAP working paper, available at: https://www.cgap.org/research/publication/role-financial-services-youth-educationand-employment (accessed 15 March 2020).

Armendáriz, B. and Morduch, J. (2010), Economics of Microfinance, 2nd edn, MIT Press, Cambridge, MA, USA.

Banerjee, S.B. and Jackson, L. (2016), "Microfinance and the business of poverty reduction: Critical perspectives from rural Bangladesh", Human Relations, Vol. 70 No. 1, pp. 6391.

Bateman, M. (2010), Why doesn't microfinance work? The destructive rise of local neoliberalism, Zed Books, London.

Bauchet, J., Damon, A. and Larsen, V. (2017), “Microfinance bundling and consumer protection: Experimental evidence from Colombia", Journal of Development Effectiveness, Vol. 9 No. 4, pp. 443-461.

Beisland, L.A., D’Espallier, B. and Mersland, R. (2019), "The commercialization of the microfinance industry: Is there a 'personal mission drift' among credit officers?" Journal of Business Ethics, Vol. 158 No. 1, pp. 119-134.

Beisland, L.A. and Mersland, R. (2012), "The use of microfinance services among economically active disabled people: Evidence from Uganda", Journal of International Development, Vol. 24 No. 1, pp. S69-S83. 
Beisland, L.A. and Mersland, R. (2014a), "Staff characteristics and the exclusion of persons with disabilities: Evidence from the microfinance industry in Uganda", Disability and Society, Vol. 29 No. 7, pp. 1061-1075.

Beisland, L.A. and Mersland, R. (2014b), "Income characteristics and the use of microfinance services: Evidence from economically active persons with disabilities", Disability and Society, Vol. 29 No. 3, pp. 417-430.

Beisland, L.A. and Mersland, R. (2017), “Exploring microfinance clients with disabilities: A case study of an Ecuadorian Microbank", The Journal of Development Studies, Vol. 53 No. 11, pp. 1929-1943.

Beisland, L.A., Mersland, R. and Zamore, S. (2016), “Motivations for business start-up: Are there any differences between disabled and non-disabled microfinance clients?", Journal of International Development, Vol. 28 No. 1, pp. 147-149.

Brickell, K., Picchioni, F., Natarajan, N., Guermond, V., Parsons, L., Zanello, G. and Bateman, M. (2020), "Compounding crises of social reproduction: Microfinance, over-indebtedness and the COVID-19 pandemic", World Development, 136, https://doi.org/https://doi.org/10.1016/j.worlddev.2020.105087

Chaudhry, V. (2016), "Living at the edge: Disability, gender, and neoliberal debtscapes of microfinance in India", Affilia, Vol. 31 No. 2, pp. 177-191.

Cramm, J.M. and Finkenflugel, H. (2008), "Exclusion of disabled people from microcredit in Africa and Asia: A literature study", Disability, CBR \& Inclusive Development, Vol. 19 No. 2, pp. 15-33.

Cramm, J.M., Paauwe, M. and Finkenflügel, H. (2012), "Facilitators and hindrances in the experiences of Ugandans with and without disabilities when seeking access to microcredit schemes", Disability and Rehabilitation, Vol. 34 No. 25, pp. 2166-2176.

Coleman, B.E. (2006), “Microfinance in northeast Thailand: Who benefits and how much?", World Development, Vol. 34 No. 9, pp. 1612-1638.

Colgan, B.P. and Kolínský, O. (2014), "Statelessness and microfinance: Can microfinance improve the living conditions of the stateless?", Tilburg Law Review, Vol. 19 No. 1-2, pp. 90-97.

Collins, D., Morduch, J. and Rutherford, S. (2009), Portfolios of the poor: How the world's poor live on \$2 a day, Princeton University Press, Princeton and Oxford.

Corsi, M. and De Angelis, M. (2017), "Gender discrimination in microfinance? Some evidence from Uganda", The Journal of Development Studies, Vol. 53 No. 5, pp. 723-740. 
Daher, H. and Flessa, S. (2010), "Microfinance as a tool for financing medical devices in Syria: An assessment of needs and a call for further research", Journal of Public Health, Vol. 18 No. 2, pp. 189-197.

Drolet, J. (2010), “Feminist perspectives in development: Implications for women and microcredit", Affilia, Vol. 25 No. 3, pp. 212-223.

Dutta, A. and Banerjee, S. (2018), "Does microfinance impede sustainable entrepreneurial initiatives among women borrowers? Evidence from rural Bangladesh", Journal of Rural Studies, Vol. 60, pp. 70-81.

Fiasse, J. (2011), "Impact of micro credit scheme for persons with physical disabilities in Herat, Afghanistan", Disability, CBR \& Inclusive Development, Vol. 22 No. 1, pp. 99-107.

Flynn, J. and Sumberg, J. (2017), "Youth savings groups in Africa: They're a family affair", Enterprise Development and Microfinance, Vol. 28, No. 3, pp. 147-161.

Flynn, J., and Sumberg, J. (2018), "Are savings groups a livelihoods game changer for young people in Africa?" Development in Practice, Vol. 28 No. 1, pp. 51-64.

Garikipati, S. (2008), "The impact of lending to women on household vulnerability and women's empowerment: Evidence from India", World Development, Vol. 36 No. 12, pp. 2620-2642.

Ghatak, M. and Guinnane, T.W. (1999), "The economics of lending with joint liability: Theory and practice", Journal of Development Economics, Vol. 60 No. 1, pp. 195-228.

Goetz, A.M. and Gupta, R.S. (1996), "Who takes the credit? Gender, power, and control over loan use in rural credit programs in Bangladesh", World Development, Vol. 24 No. 1, pp. 45-63.

Guérin, I., D'Espallier, B. and Venkatasubramanian, G. (2015), "The social regulation of markets: Why microcredit fails to promote jobs in rural South India", Development and Change, Vol. 46 No. 6, pp. 1277-1301.

Hammill, A., Matthew, R. and McCarter, E. (2008), “Microfinance and climate change adaptation", IDS Bulletin, Vol. 39 No. 4, pp. 113-122.

Heeren, M.-J.J., Ky, L. and van Brakel, W.H. (2014), “Perceived needs related to social participation of people with Leprosy-related disabilities and other people with disabilities in Cambodia: A qualitative study", Disability, CBR \& Inclusive Development, Vol. 25 No. 3, pp. 24-44.

Hermes, N. and Lensink, R. (2011), "Microfinance: Its impact, outreach, and sustainability", World Development, Vol. 39 No. 6, pp. 875-881. 
Hulme, D. (2004), "Thinking 'small' and the understanding of poverty: Maymana and Mofizul's story", Journal of Human Development, Vol. 5 No. 2, pp. 161-176.

Idris, M. (2019), "A microenterprise initiative among newly resettled refugees in a city of the U.S. South: Challenges, successes, and lessons learned", Annals of Anthropological Practice, Vol. 43 No. 2, pp. 39-52.

Kabeer, N. (1999), "Resources, agency, achievements: Reflections on the measurement of women's empowerment", Development and Change, Vol. 30 No. 3, pp. 435-464.

Kabeer, N. (2005), “Gender equality and women's empowerment: A critical analysis of the third millennium development goal 1", Gender and Development, Vol. 13 No. 1, pp. 1324.

Karim, L. (2011), Microfinance and its discontents: Women in debt in Bangladesh, University of Minnesota Press, Minneapolis.

Kayser, K., Lombe, M., Newransky, C., Tower, G. and Raj, P. (2010), "Self-help microcredit programs for widowed and abandoned women in South India: Do they help?", Journal of Social Service Research, Vol. 36 No. 1, pp. 12-23.

Kazianga, H. and Wahhaj, Z. (2020), "Will urban migrants formally insure their rural relatives? Family networks and rainfall index insurance in Burkina Faso", World Development, 128, https://doi.org/10.1016/j.worlddev.2019.104764

Khandelwal, M. and Freeman, C. (2017), "Pop development and the uses of feminism", in Batman, M. and Maclean, K. (Eds.), Seduced and Betrayed: Exposing the Contemporary Microfinance Phenomenon, University of New Mexico Press, Albuquerque, published in Association with School for Advanced Research Press, Santa Fe, pp. 49-67.

Khandker, S.H. (2005), “Microfinance and poverty: Evidence using panel data from Bangladesh", The World Bank Economic Review, Vol. 19 No, 2, pp. 263-286.

Labie, M., Méon, P-G., Mersland R. and Szafarz, A. (2015), "Discrimination by microcredit officers: Theory and evidence on disability in Uganda", Quarterly Review of Economics and Finance, Vol. 58, pp. 44-55.

Lall, P., Shaw, S.A., Saifi, R., Sherman, S.G., Nor Azmi, N., Pillai, V., El-Bassel, N., Kamarulzaman, A. and Wickersham, J.A. (2017), "Acceptability of a microfinance-based empowerment intervention for transgender and cisgender women sex workers in Greater Kuala Lumpur, Malaysia", Journal of the International AIDS Society, Vol. 20, http://dx.doi.org/10.7448/IAS.20.1.21723 
Ledgerwood. J. and Gibson A. (2013), "The evolving financial landscape", in Ledgerwood, J., Earne, J. and Nelson, C. (Eds), The New Microfinance Handbook: A Financial Market System Perspective, The World Bank, Washington DC, pp. 15-48.

Lévesque, M. and Minniti, M. (2006), "The effect of aging on entrepreneurial behavior", Journal of Business Venturing, Vol. 21 No. 2, pp. 177-194.

Lewis, C. (2004), "Microfinance from the point of view of women with disabilities: Lessons from Zambia and Zimbabwe" Gender and Development, Vol. 12 No. 1, pp. 28-39.

Li, X., Gan, C. and Hu, B. (2011), "The impact of microcredit on women's empowerment: Evidence from China", Journal of Chinese Economic and Business Studies, Vol. 9 No. 3, pp. 239-261.

Lowicki-Zucca, M., Walugembe, P., Ogaba, I. and Langol, S. (2014), "Savings groups as a socioeconomic strategy to improve protection of moderately and critically vulnerable children in Uganda", Children and Youth Services Review, Vol. 47 No. 2, pp. 176-181.

Maclean, K. (2017), “Microfinance and the 'woman' question”, in Bateman, M. and Maclean, K. (Eds.), Seduced and Betrayed: Exposing the Contemporary Microfinance Phenomenon, University of New Mexico Press, Albuquerque, published in Association with School for Advanced Research Press, Santa Fe, pp. 251-264.

Mahmood, S. (2011), "Microfinance and women entrepreneurs in Pakistan", International Journal of Gender and Entrepreneurship, Vol. 3 No. 3, pp. 265-274.

Mersland, R., Bwire, F.N. and Mukasa, G. (2009), "Access to mainstream microfinance services for persons with disabilities: Lessons learned from Uganda", Disability Studies Quarterly, Vol. 29 No. 1, https://ssrn.com/abstract=1101701

Moher, D., Liberati, A., Tetzlaff, J. and Altman, D.G. (2009), “Preferred reporting items for systematic reviews and meta-analyses: The PRISMA statement", BMJ, Vol. 339, b2535, https://doi.org/10.1136/bmj.b2535

Murshid, N.S. (2019), "Microfinance participation, control over resources, and justification of IPV: Results from a nationally representative sample of women", Journal of Interpersonal Violence, Vol. 34 No. 3, pp. 475-495.

Nair, S., Jagannathan, A., Kudumallige, S., Kumar, C.N. and Thirthalli, C. (2018), “Need for micro-finance self-help groups among women family caregivers of persons with mental disability in rural India", Mental Health and Social Inclusion, Vol. 22 No. 1, pp. 34-45. 
Nuwagaba, E.L., Nakabugo, M., Tumukunde, M., Ngirabakunzi, E., Hartley, S. and Wade, A. (2012), "Accessibility to micro-finance services by people with disabilities in Bushenyi District, Uganda", Disability and Society, Vol. 27 No. 2, pp. 175-190.

Paprocki, K. (2016), “'Selling our own skin:' Social dispossession through microcredit in rural Bangladesh", Geoforum, Vol. 74, pp. 29-38.

Parvin, G.A. and Shaw, R. (2013), "Microfinance institutions and a coastal community's disaster risk reduction, response, and recovery process: A case study of Hatiya, Bangladesh", Disasters, Vol. 37 No. 1, pp. 165-184.

Pearlman, S. (2012), "Too vulnerable for microfinance? Risk and vulnerability as determinants of microfinance selection in Lima", The Journal of Development Studies, Vol. 48 No. 9, pp. 1342-1359.

Pitt, M.M. and Khandker, S.H. (1998), "The impact of group-based credit programs on poor households in Bangladesh: Does the gender of participants matter?", The Journal of Political Economy, Vol. 106 No. 2, pp. 958-996.

Polu, W., Mong, A. and Nelson, C. (2015), "Social and economic inclusion of people with disabilities: practical lessons from Bangladesh", Development in Practice, Vol. 25 No. 8 , pp. 1182-1188.

Rahman, A. (1999), "Microcredit initiatives for equitable and sustainable development: Who pays?" World Development, Vol. 27 No.1, pp. 67-82.

Ray-Bennett, N.S. (2010), "The role of microcredit in reducing women's vulnerabilities to multiple disasters", Disasters, Vol. 34 No. 1, pp. 240-260.

Sarker, D. (2013), “Microfinance for disabled people: How is it contributing?", Research Journal of Finance and Accounting, Vol. 4 No. 9, DOI: 10.7176/RJFA/4-9-118

Sarker, D. (2020), "Discrimination against people with disabilities in accessing microfinance", Alter, Vol. 14 No. 4, pp.318-328.

Sigalla, R.J. and Carney, S. (2012), "Poverty reduction through entrepreneurship: Microcredit, learning and ambivalence amongst women in urban Tanzania", International Journal of Educational Development, Vol. 32 No. 4, pp. 546-554.

Swain, R.B. and Floro, M. (2012), "Assessing the effect of microfinance on vulnerability and poverty among low income households", The Journal of Development Studies, Vol. 48 No. 5, pp. 605-618. 
Tanima, F.A., Brown, J. and Dillard, J. (2020), "Surfacing the political: Women's empowerment, microfinance, critical dialogic accounting and accountability", Accounting, Organizations and Society, Vol. 85, https://doi.org/10.1016/j.aos.2020.101141

Theophilus, K.A. and Paul, S-M. (2019), "The imact of savings groups on female agency: Insights from village savings and loan associations in Northern Ghana", Asian Journal of Agriculture and Rural Development, Vol. 9 No. 2, pp. 133-146.

Thomas, M. (2000), “Feasibility of integrating people with disabilities in savings and credit programmes in Bangladesh", Asia Pacific Disability Rehabilitation Journal, Vol. 11 No. 1, pp. 27-31.

Thorpe, R., Holt, R., Macpherson, A. and Pittaway, L. (2005), “Using knowledge within small and medium-sized firms: A systematic review of the evidence", International Journal of Management Reviews, Vol. 7 No. 4, pp. 257-281.

Tranfield, D., Denyer, D. and Smart, P. (2003), "Towards a methodology for developing evidence-informed management knowledge by means of systematic review", British Journal of Management, Vol. 14, pp. 207-222.

Tundui, H.P. and Tundui, C.S. (2020), "Performance drivers of women-owned microcredit funded enterprises in Tanzania", International Journal of Gender and Entrepreneurship, Vol. 12 No. 2, pp. 211-230.

ul Haque, A., Kot, S. and Imran, M. (2019), "The moderating role of environmental disaster in relation to microfinance's non-financial services and women's micro-enterprise sustainability", Journal of Security and Sustainability Issues, Vol. 8 No. 3, pp. 355-373.

Weber, H. (2016), "Gender and microfinance/microcredit", in Mann, E. (Ed.), Handbook on Gender in World Politics, Edward Elgar Publishing, Florida, pp. 430-437.

Welter, F. (2011), "Contextualizing entrepreneurship: Conceptual challenges and ways forward", Entrepreneurship Theory and Practice, Vol. 35 No. 1, pp. 165-184.

Wright, K. (2006), "The darker side to microfinance - evidence from Cajamaru, Peru", in Fernando, J. (Ed.), Microfinance - Perils and Prospects, Routledge, London and New York, pp. 133-149.

Wilson K. (2015), “Towards a radical re-appropriation: Gender, development and neoliberal feminism", Development and Change, Vol. 46 No. 4, pp. 803-832. 
Table 1: Summary of the articles in each category

\begin{tabular}{|c|c|c|}
\hline Category & $\begin{array}{l}\text { Number } \\
\text { of articles }\end{array}$ & Overlap of articles with another category \\
\hline Disability & 20 & $\begin{array}{l}\text { One article overlapped with widows/female- } \\
\text { headed households. }\end{array}$ \\
\hline $\begin{array}{l}\text { Natural disasters or } \\
\text { climate change risks }\end{array}$ & 7 & $\begin{array}{l}\text { Two articles overlapped with widows/female- } \\
\text { headed households. }\end{array}$ \\
\hline $\begin{array}{l}\text { Widows or female- } \\
\text { headed households }\end{array}$ & 5 & Three articles overlapped with other categories. \\
\hline $\begin{array}{l}\text { Youth/young people } \\
\text { Refugees }\end{array}$ & $\begin{array}{l}3 \\
2\end{array}$ & 7 No overlaps with other categories. \\
\hline Cisgender/transgender & 1 & $J$ \\
\hline
\end{tabular}

Table 2: Sources and types of articles

\begin{tabular}{|c|c|c|c|}
\hline \multirow[t]{2}{*}{ SJR* } & \multirow[t]{2}{*}{ Journal name } & \multirow[t]{2}{*}{ Article/s } & \multirow{2}{*}{$\begin{array}{c}\text { Type of study and number } \\
\text { of articles }\end{array}$} \\
\hline & & & \\
\hline \multirow[t]{2}{*}{2.67} & Journal of the & Lall et al., 2017 & Empirical (qualitative): 1 \\
\hline & International AIDS Society & & \\
\hline \multirow[t]{2}{*}{2.22} & World Development & Kazianga \& Wahhaj, & Empirical: 1 \\
\hline & & 2020 & \\
\hline 1.97 & Journal of Business Ethics & Beisland et al., 2019 & Empirical (mixed method): 1 \\
\hline \multirow[t]{2}{*}{0.92} & The Journal of & Beisland \& Mersland, & Empirical: 1 \\
\hline & Development Studies & 2017 & \\
\hline \multirow[t]{2}{*}{0.81} & Journal of Development & Bauchet et al., 2017 & Empirical: 1 \\
\hline & Effectiveness & & \\
\hline \multirow[t]{2}{*}{0.80} & Children and Youth & Lowicki-Zucca et al., & Empirical: 1 \\
\hline & Services Review & 2014 & \\
\hline \multirow[t]{2}{*}{0.79} & Disability and & Cramm et al., 2012 & Empirical ( $Q$ method): 1 \\
\hline & Rehabilitation & & \\
\hline \multirow[t]{3}{*}{0.70} & Disability and Society & Beisland \& Mersland, & Empirical: 3 (one paper with \\
\hline & & 2014a, 2014b; & mixed method) \\
\hline & & Nuwagaba et al., 2012 & \\
\hline \multirow[t]{2}{*}{0.61} & Disasters & Parvin \& Shaw, 2013; & Empirical: 2 (one paper with \\
\hline & & Ray-Bennett, 2010 & qualitative) \\
\hline
\end{tabular}




\begin{tabular}{|c|c|c|c|}
\hline 0.61 & $\begin{array}{l}\text { Journal of International } \\
\text { Development }\end{array}$ & $\begin{array}{l}\text { Beisland et al., 2016; } \\
\text { Beisland \& Mersland, } \\
2012\end{array}$ & $\begin{array}{l}\text { Other (field report): } 1 \\
\text { Empirical: } 1\end{array}$ \\
\hline 0.58 & $\begin{array}{l}\text { Quarterly Review of } \\
\text { Economics and Finance }\end{array}$ & Labie et al., 2015 & Empirical: 1 \\
\hline 0.52 & Gender and Development & Lewis, 2004 & $\begin{array}{l}\text { Other (a symposium } \\
\text { synthesis): } 1\end{array}$ \\
\hline 0.52 & $\begin{array}{l}\text { Journal of Family Business } \\
\text { Management }\end{array}$ & Acheampong, 2018 & Empirical: 1 \\
\hline 0.51 & Affilia & Chaudhry, 2016 & Empirical (qualitative): 1 \\
\hline 0.40 & $\begin{array}{l}\text { Enterprise Development } \\
\text { and Microfinance }\end{array}$ & Flynn \& Sumberg, 2017 & Empirical: 1 \\
\hline 0.38 & $\begin{array}{l}\text { Journal of Security and } \\
\text { Sustainability Issues }\end{array}$ & ul Haque et al., 2019 & Empirical: 1 \\
\hline 0.37 & Development in Practice & $\begin{array}{l}\text { Polu et al., 2015; Flynn \& } \\
\text { Sumberg, } 2018\end{array}$ & $\begin{array}{l}\text { Other (practical note): } 1 \\
\text { Empirical: } 1\end{array}$ \\
\hline 0.32 & $\begin{array}{l}\text { Annals of Anthropological } \\
\text { Practice }\end{array}$ & Idris, 2019 & Empirical (qualitative): 1 \\
\hline 0.31 & $\begin{array}{l}\text { Mental Health and Social } \\
\text { Inclusion }\end{array}$ & Nair et al., 2018 & Empirical (mixed method): 1 \\
\hline 0.3 & $\begin{array}{l}\text { Journal of Social Service } \\
\text { Research }\end{array}$ & Kayser et al., 2010 & Empirical: 1 \\
\hline 0.22 & IDS Bulletin & Hammill et al., 2008 & Conceptual: 1 \\
\hline 0.17 & $\begin{array}{l}\text { Asia Pacific Disability } \\
\text { Rehabilitation Journal }\end{array}$ & $\begin{array}{l}\text { Cramm \& Finkenflugel, } \\
\text { 2008; Thomas, 2000; } \\
\text { Fiasse, 2011; }\end{array}$ & $\begin{array}{l}\text { Literature review: } 1 \\
\text { Other: } 1 \text { (brief report) } \\
\text { Empirical: } 1 \text { (qualitative) }\end{array}$ \\
\hline 0.13 & Tilburg Law Review & Colgan \& Kolínský, 2014 & $\begin{array}{l}\text { Other (a conceptual paper } \\
\text { with illustrative cases): } 1\end{array}$ \\
\hline 0.00 & $\begin{array}{l}\text { Asian Journal of } \\
\text { Agriculture and Rural } \\
\text { Development }\end{array}$ & Theophilus \& Paul, 2019 & Empirical (mixed method): 1 \\
\hline $\mathrm{N} / \mathrm{A}$ & $\begin{array}{l}\text { Disability Studies } \\
\text { Quarterly }\end{array}$ & Mersland et al., 2009 & $\begin{array}{l}\text { Empirical (a project analysis): } \\
1\end{array}$ \\
\hline $\mathrm{N} / \mathrm{A}$ & $\begin{array}{l}\text { Research Journal of } \\
\text { Finance and Accounting }\end{array}$ & Sarker, 2013 & Other (a critical analysis): 1 \\
\hline $\mathrm{N} / \mathrm{A}$ & ALTER & Sarker, 2020 & Other (a short report): 1 \\
\hline $\mathrm{N} / \mathrm{A}$ & $\begin{array}{l}\text { Disability, CBR \& Inclusive } \\
\text { Development }\end{array}$ & Heeren et al., 2014 & Empirical (qualitative): 1 \\
\hline $\mathrm{N} / \mathrm{A}$ & Journal of Public Health & Daher \& Flessa, 2010 & Empirical: 1 \\
\hline
\end{tabular}

*SCImago Journal Rank 
Table 3: Potential future research areas

\begin{tabular}{|c|c|}
\hline Empc & Research area \\
\hline $\begin{array}{l}\text { Women's agen } \\
\text { accessing and } \\
\text { utilising } \\
\text { microfinance }\end{array}$ & $\begin{array}{l}\text { - Use of microfinance services by different vulnerable groups } \\
\text { (especially among older women, young women, refugees, widows } \\
\text { or female-headed households, and gay and lesbian communities) } \\
\text { - Geographical and contextual differences in how vulnerable } \\
\text { women use microfinance services and exercise agency } \\
\text { - Ways contextual or life cycle shocks, including COVID-19 pandemic, } \\
\text { and insurance) and exercise of agency } \\
\text { Women's decision-making, resilience, adaptability and coping } \\
\text { mechanisms when they experience contextual or life cycle shocks }\end{array}$ \\
\hline $\begin{array}{l}\text { Resources that } \\
\text { shape women's } \\
\text { agency }\end{array}$ & $\begin{array}{l}\text { - Extent to which individual, household, MFI and community level } \\
\text { factors mediate or moderate access and utilisation of } \\
\text { microfinance services } \\
\text { - Ways which transformative actions shape or reshape individual, } \\
\text { household, MFI and community level resources in accessing and } \\
\text { utilising microfinance services }\end{array}$ \\
\hline $\begin{array}{l}\text { Achievement: extent } \\
\text { to which } \\
\text { entrepreneurial } \\
\text { potential is realised }\end{array}$ & $\begin{array}{l}\text { - Extent to which individual, household, MFI and community level } \\
\text { factors mediate or moderate entrepreneurial self-efficacy or } \\
\text { business start-up and development intentions or actions }\end{array}$ \\
\hline
\end{tabular}




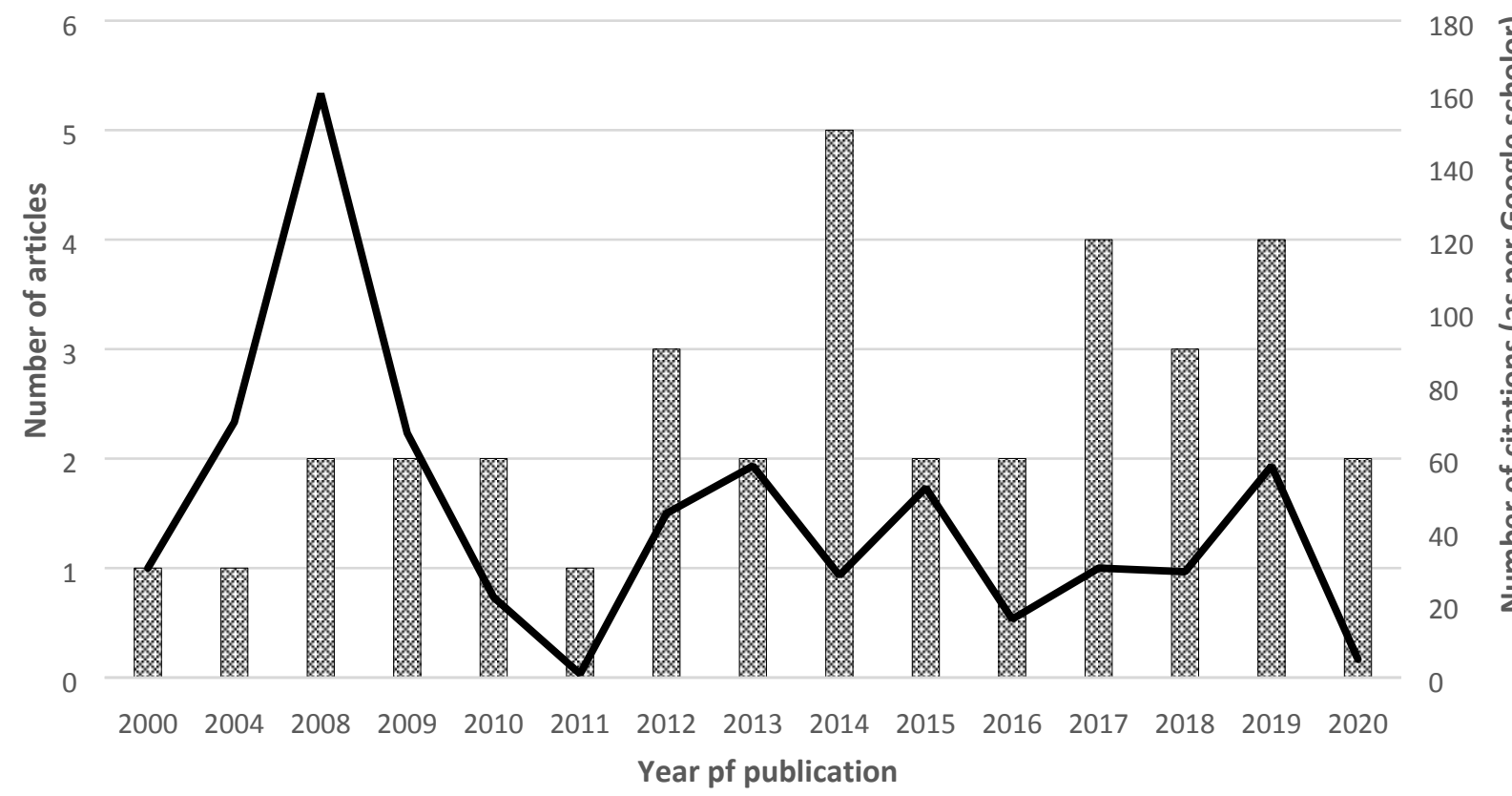

Figure 1: Number of articles and total citations according to year of publication

42 


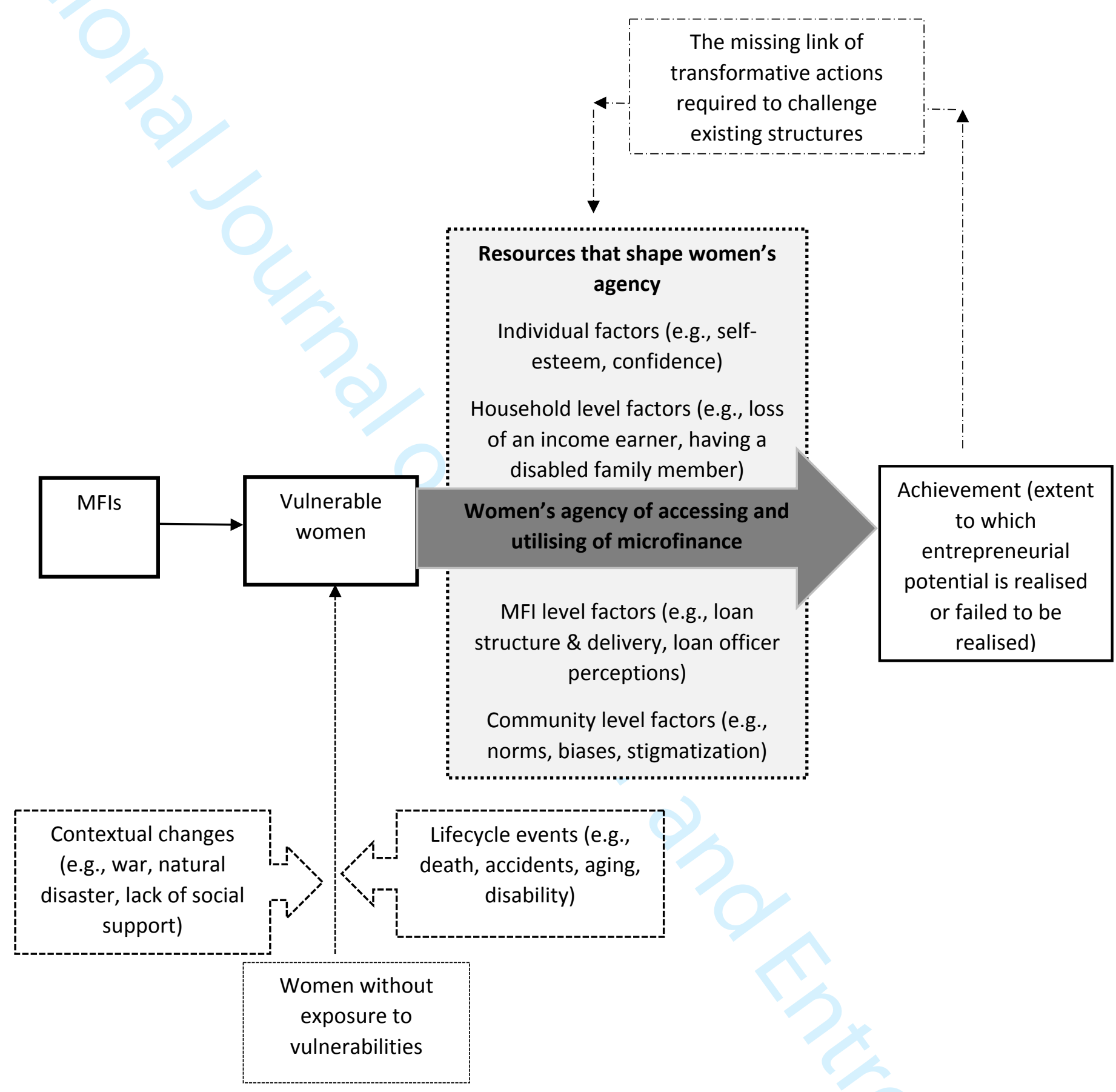

Figure 2: Process of economic empowerment of vulnerable women microfinanceentrepreneurs 
Online supplementary: Summary of the articles

\begin{tabular}{|c|c|c|c|c|c|}
\hline 0 & & & Online supplementar & : Summary & he articles \\
\hline $\begin{array}{l}\text { Category and } \\
\text { theme }\end{array}$ & Article & $\begin{array}{l}\text { Type of } \\
\text { article }\end{array}$ & $\begin{array}{c}\text { Theory or } \\
\text { conceptual framing }\end{array}$ & Country & Key findings \\
\hline & & & Disability a & d microfina & \\
\hline $\begin{array}{l}\text { Use (or non-use) } \\
\text { of microfinance } \\
\text { by disabled } \\
\text { people or their } \\
\text { caregivers for }\end{array}$ & $\begin{array}{l}\text { Beisland \& } \\
\text { Mersland } \\
2012\end{array}$ & Empirical & $\begin{array}{l}\text { No specific theory } \\
\text { (Article is framed } \\
\text { around financial } \\
\text { inclusion and } \\
\text { access) }\end{array}$ & Uganda & $\begin{array}{l}\text { Informal self-help schemes are more easily accessible for } \\
\text { people with disabilities than formal institutional schemes. } \\
\text { They also make use of savings services more than loans. }\end{array}$ \\
\hline entrepreneurship & $\begin{array}{l}\text { Beisland \& } \\
\text { Mersland } \\
2017\end{array}$ & Empirical & No specific theory & Ecuador & $\begin{array}{l}\text { Among people with disabilities there is a tendency to save } \\
\text { more. }\end{array}$ \\
\hline & $\begin{array}{l}\text { Nuwagaba et } \\
\text { al. } 2012\end{array}$ & Empirical & Poverty alleviation & Uganda & $\begin{array}{l}\text { Disability per se does not negatively affect access to } \\
\text { microfinance services. Failure to access microfinance services } \\
\text { is the outcome of a complex and dynamic interaction of } \\
\text { individual, MFI and context related factors. }\end{array}$ \\
\hline & $\begin{array}{l}\text { Chaudhry } \\
2016 \text { (some } \\
\text { overlap with } \\
\text { widows) }\end{array}$ & Empirical & $\begin{array}{l}\text { Critical disability } \\
\text { feminist } \\
\text { perspective }\end{array}$ & India & $\begin{array}{l}\text { The current development models and interventions, such as } \\
\text { microfinance, are ill-suited to redress the conditions of } \\
\text { impairment that affect disabled women. These interventions } \\
\text { do not take into account cultural aspects of power and how } \\
\text { power is manifested in communities. }\end{array}$ \\
\hline & $\begin{array}{l}\text { Beisland \& } \\
\text { Mersland } \\
\text { 2014a }\end{array}$ & Empirical & No specific theory & Uganda & $\begin{array}{l}\text { In Uganda, among people with disabilities, the relationship } \\
\text { between economic activity, income and access to } \\
\text { microfinance mirror the general population trend. } \\
\text { Furthermore persons with disabilities, whose primary income } \\
\text { source is farming, have considerably less access to formal } \\
\text { microfinance services than others. }\end{array}$ \\
\hline
\end{tabular}


Online supplementary: Summary of the articles

\begin{tabular}{|c|c|c|c|c|c|}
\hline \multicolumn{6}{|c|}{ Online supplementary: Summary of the articles } \\
\hline $\begin{array}{l}\text { Category and } \\
\text { theme }\end{array}$ & Article & $\begin{array}{l}\text { Type of } \\
\text { article }\end{array}$ & $\begin{array}{c}\text { Theory or } \\
\text { conceptual framing }\end{array}$ & Country & Key findings \\
\hline & $\begin{array}{l}\text { Beisland et al. } \\
2016\end{array}$ & $\begin{array}{l}\text { Empirical } \\
\text { (field report) }\end{array}$ & $\begin{array}{l}\text { No specific theory } \\
\text { (but uses the start- } \\
\text { up motivation to } \\
\text { frame the } \\
\text { arguments) }\end{array}$ & Ecuador & $\begin{array}{l}\text { Among microfinance borrowers, there is no significant } \\
\text { difference in motivation for business start-up between } \\
\text { persons with and without disabilities. }\end{array}$ \\
\hline & Sarker 2013 & Review & $\begin{array}{l}\text { Discrimination and } \\
\text { poverty }\end{array}$ & 0 & $\begin{array}{l}\text { Disabled people are a significant target market for MFIs. } \\
\text { However, disabled people require services, other than saving } \\
\text { and credit, such as training programs on entrepreneurial } \\
\text { skills and financial literacy. MFls also need to be inclusive in } \\
\text { their recruitment, training and orientation programs to } \\
\text { enhance understanding about disabled people. }\end{array}$ \\
\hline & $\begin{array}{l}\text { Nair et al. } \\
2018\end{array}$ & Empirical & No & India & $\begin{array}{l}\text { Microfinance groups comprised of caregivers of persons with } \\
\text { mental disability could ease the financial burden of a } \\
\text { household. Due to the time required for caregiving, } \\
\text { understanding the skills/capacity of the caregiver and } \\
\text { resources available at the community need to be considered } \\
\text { when planning microfinance-led entrepreneurial programs } \\
\text { for caregivers. }\end{array}$ \\
\hline & $\begin{array}{l}\text { Polu et al. } \\
2015\end{array}$ & $\begin{array}{l}\text { Empirical: } \\
\text { program } \\
\text { analysis }\end{array}$ & No & Bangladesh & $\begin{array}{l}\text { Empowerment approach has potential to reduce self-stigma } \\
\text { and increase a sense of inclusion in the wider community. } \\
\text { The training in self-care is more important than even } \\
\text { livelihood training. }\end{array}$ \\
\hline $\begin{array}{l}\text { Challenges and } \\
\text { barriers faced by } \\
\text { disabled people }\end{array}$ & $\begin{array}{l}\text { Beisland et al. } \\
2019\end{array}$ & Empirical & $\begin{array}{l}\text { Mission drift is } \\
\text { used as the main } \\
\text { concept to frame }\end{array}$ & Ecuador & $\begin{array}{l}\text { Credit officer experience is negatively correlated with the } \\
\text { provision of loans to persons with disabilities. This is mainly } \\
\text { due to the perceived risk and increased time required to }\end{array}$ \\
\hline
\end{tabular}




\section{Online supplementary: Summary of the articles}

\begin{tabular}{|c|c|c|c|c|c|}
\hline \multicolumn{6}{|c|}{ Online supplementary: Summary of the articles } \\
\hline $\begin{array}{l}\text { Category and } \\
\text { theme }\end{array}$ & Article & $\begin{array}{l}\text { Type of } \\
\text { article }\end{array}$ & $\begin{array}{c}\text { Theory or } \\
\text { conceptual framing }\end{array}$ & Country & Key findings \\
\hline \multirow{6}{*}{$\begin{array}{l}\text { in accessing } \\
\text { microfinance for } \\
\text { entrepreneurship }\end{array}$} & & & the article & & $\begin{array}{l}\text { serve these borrowers. The institutional incentive schemes } \\
\text { seem to be reinforcing this thinking. }\end{array}$ \\
\hline & $\begin{array}{l}\text { Beisland \& } \\
\text { Mersland } \\
\text { 2014b }\end{array}$ & Empirical & $\begin{array}{l}\text { No specific theory } \\
\text { or concept (uses } \\
\text { staff discrimination } \\
\text { in accessing } \\
\text { microfinance to } \\
\text { frame the article) }\end{array}$ & Uganda & $\begin{array}{l}\text { Different staff members in MFIs have different views and } \\
\text { beliefs regarding customers with disabilities. The younger } \\
\text { staff members are more positive and optimistic regarding the } \\
\text { potential to reach more clients with disabilities. The credit } \\
\text { officers are also more likely than others to suggest that } \\
\text { discrimination could be a problem. }\end{array}$ \\
\hline & $\begin{array}{l}\text { Mersland et al. } \\
2009\end{array}$ & Empirical & $\begin{array}{l}\text { Different types of } \\
\text { exclusions are used } \\
\text { to frame the article }\end{array}$ & Uganda & $\begin{array}{l}\text { Entrepreneurs with disabilities are an untapped market for } \\
\text { microfinance services. However, they get excluded from } \\
\text { microfinance services due to low self-esteem, perceptions of } \\
\text { other members or staff and design practices or physical or } \\
\text { informational barriers. Special interventions addressing these } \\
\text { areas are required for disabled people access to microfinance } \\
\text { services. }\end{array}$ \\
\hline & $\begin{array}{l}\text { Cramm, \& } \\
\text { Finkenflugel } \\
2008\end{array}$ & $\begin{array}{l}\text { Literature } \\
\text { review }\end{array}$ & No & No & $\begin{array}{l}\text { The self-exclusion, exclusion by others, exclusion by staff and } \\
\text { exclusion by design are all present, within both institutional } \\
\text { schemes and self-help schemes. }\end{array}$ \\
\hline & $\begin{array}{l}\text { Labie et al. } \\
2014\end{array}$ & Empirical & Discrimination & Uganda & $\begin{array}{l}\text { It is found that loan officers are more biased than other MFI } \\
\text { employees against disabled micro-entrepreneurs. However, } \\
\text { socially-oriented MFIs could mitigate discrimination by } \\
\text { designing 'right' incentive schemes. }\end{array}$ \\
\hline & Sarker 2020 & $\begin{array}{l}\text { Empirical: } \\
\text { Short report }\end{array}$ & Discrimination & No & $\begin{array}{l}\text { The attitudes and perception of staff is one of the main } \\
\text { factors of discrimination of disabled people from } \\
\text { microfinance services. People with disabilities are subjected }\end{array}$ \\
\hline
\end{tabular}


Online supplementary: Summary of the articles

\begin{tabular}{|c|c|c|c|c|c|}
\hline \multicolumn{6}{|c|}{ Online supplementary: Summary of the articles } \\
\hline $\begin{array}{l}\text { Category anc } \\
\text { theme }\end{array}$ & Article & $\begin{array}{l}\text { Type of } \\
\text { article }\end{array}$ & $\begin{array}{c}\text { Theory or } \\
\text { conceptual framing }\end{array}$ & Country & Key findings \\
\hline & & & & & $\begin{array}{l}\text { to 'taste-based discrimination' (prejudice) and 'statistical } \\
\text { discrimination' (when MFI staff uses individuals' disability as } \\
\text { an indication of entrepreneurial potential). Hence, people } \\
\text { with disabilities tend not to apply for microfinance due to the } \\
\text { anticipation of such rejection. }\end{array}$ \\
\hline & Lewis 2004 & $\begin{array}{l}\text { Synthesis: } \\
\text { International } \\
\text { Symposium } \\
\text { on Issues of } \\
\text { Women with } \\
\text { Disabilities }\end{array}$ & Exclusion & $\begin{array}{l}\text { Zambia and } \\
\text { Zimbabwe }\end{array}$ & $\begin{array}{l}\text { Disabled women who access microfinance services face } \\
\text { challenges associated with the business. They also face } \\
\text { accessibility and discrimination at institutions. Disabled } \\
\text { women require solutions that bridge the gap and build their } \\
\text { capacity. }\end{array}$ \\
\hline & Thomas 2000 & Empirical & Exclusion & Bangladesh & $\begin{array}{l}\text { Multiple factors influence effective inclusion of people with } \\
\text { disabilities into savings and credit programmes. }\end{array}$ \\
\hline & $\begin{array}{l}\text { Cramm et al. } \\
2012\end{array}$ & Empirical & Exclusion & Uganda & $\begin{array}{l}\text { Persons with disabilities prefer individual loans. Their } \\
\text { disability-specific circumstances need to be included in } \\
\text { microcredit schemes for people with disabilities to get } \\
\text { maximum benefit. }\end{array}$ \\
\hline & $\begin{array}{l}\text { Heeren et al. } \\
2014 .\end{array}$ & Empirical & Exclusion & Cambodia & $\begin{array}{l}\text { People with leprosy-related disabilities and other disabilities } \\
\text { still struggle with social and economic exclusion. Socio- } \\
\text { economic rehabilitation programs need to improve their self- } \\
\text { esteem for wider economic benefit. }\end{array}$ \\
\hline $\begin{array}{l}\text { Use of } \\
\text { microfinance for } \\
\text { rehabilitation } \\
\text { leading to }\end{array}$ & $\begin{array}{l}\text { Daher \& Flessa } \\
2010\end{array}$ & Empirical & $\begin{array}{l}\text { Evolution of } \\
\text { microfinance is } \\
\text { used to frame the } \\
\text { article }\end{array}$ & Syria & $\begin{array}{l}\text { Microfinance has potential as a tool for financing medical } \\
\text { devices for disabled in Syria. }\end{array}$ \\
\hline
\end{tabular}


Online supplementary: Summary of the articles

\begin{tabular}{|c|c|c|c|c|c|}
\hline \multicolumn{6}{|c|}{ Online supplementary: Summary of the articles } \\
\hline $\begin{array}{l}\text { Category and } \\
\text { theme }\end{array}$ & Article & $\begin{array}{l}\text { Type of } \\
\text { article }\end{array}$ & $\begin{array}{c}\text { Theory or } \\
\text { conceptual framing }\end{array}$ & Country & Key findings \\
\hline entrepreneurship & Fiasse 2011 & $\begin{array}{l}\text { Empirical: } \\
\text { Brief report }\end{array}$ & No & Afghanistan & $\begin{array}{l}\text { A micro credit scheme operated by a physical rehabilitation } \\
\text { centre in Herat, Afghanistan found that staff at the centre } \\
\text { build confidence. However, paraplegics patients seem to be } \\
\text { less motivated for socioeconomic rehabilitation and engaging } \\
\text { in income generating projects. }\end{array}$ \\
\hline \multicolumn{6}{|c|}{ Disasters, risk reduction and microfinance } \\
\hline \multirow[t]{4}{*}{$\begin{array}{l}\text { Use of } \\
\text { microfinance for } \\
\text { disaster risk } \\
\text { reduction and } \\
\text { recovery }\end{array}$} & $\begin{array}{l}\text { Hammill et al. } \\
2008\end{array}$ & Conceptual & $\begin{array}{l}\text { Bundling of } \\
\text { insurance products } \\
\text { with credit }\end{array}$ & No & $\begin{array}{l}\text { Microfinance (credit, savings and insurance) contributes to } \\
\text { management of financial social, natural, human and physical } \\
\text { resources and these could help in climate change adaption. } \\
\text { However, these services need to be matched according to } \\
\text { the requirements of different client groups. }\end{array}$ \\
\hline & $\begin{array}{l}\text { Ray-Bennett } \\
2010 \text { (overlaps } \\
\text { with } \\
\text { widows/single } \\
\text {-headed } \\
\text { households) } \\
\end{array}$ & Empirical & $\begin{array}{l}\text { Women's } \\
\text { vulnerability to } \\
\text { disasters }\end{array}$ & India & $\begin{array}{l}\text { Among single-headed households, prone to multiple natural } \\
\text { disasters, inefficient microcredit delivery can re-intensified } \\
\text { local gender and class hierarchies. The effective financial } \\
\text { services require the integration of social context and need } \\
\text { effective disaster management between government, non- } \\
\text { government and other supporting agencies. }\end{array}$ \\
\hline & $\begin{array}{l}\text { ul Haque et al. } \\
2019\end{array}$ & Empirical & $\begin{array}{l}\text { Mayoux's feminist } \\
\text { empowerment } \\
\text { theory and } \\
\text { relational theory of } \\
\text { risk }\end{array}$ & $\begin{array}{l}\text { Malaysia and } \\
\text { Pakistan }\end{array}$ & $\begin{array}{l}\text { The environmental disasters have a significant effect on } \\
\text { women micro enterprise sustainability and it moderates the } \\
\text { relationship between 'micro training' and women's micro- } \\
\text { enterprise sustainability. }\end{array}$ \\
\hline & $\begin{array}{l}\text { Parvin and } \\
\text { Shaw, } 2013\end{array}$ & Empirical & $\begin{array}{l}\text { Disaster risk } \\
\text { reduction, }\end{array}$ & Bangladesh & $\begin{array}{l}\text { MFI support facilitates disaster risk reduction, response, and } \\
\text { recovery process. Length of membership in MFIs seems to be }\end{array}$ \\
\hline
\end{tabular}


Online supplementary: Summary of the articles

\begin{tabular}{|c|c|c|c|c|c|}
\hline \multicolumn{6}{|c|}{ Online supplementary: Summary of the articles } \\
\hline \multirow[t]{3}{*}{$\begin{array}{l}\text { Category and } \\
\text { theme }\end{array}$} & Article & $\begin{array}{l}\text { Type of } \\
\text { article }\end{array}$ & $\begin{array}{c}\text { Theory or } \\
\text { conceptual framing }\end{array}$ & Country & Key findings \\
\hline & & & $\begin{array}{l}\text { recovery, and } \\
\text { response }\end{array}$ & & related to preparedness for natural disasters. \\
\hline & $\begin{array}{l}\text { Kayser et al. } \\
2010 \\
\text { (overlaps with } \\
\text { widows/single } \\
\text {-headed } \\
\text { households) }\end{array}$ & Empirical & Empowerment & India & $\begin{array}{l}\text { Loans should be provided according to women's needs. It } \\
\text { should not be too large, as it may impose the burden of } \\
\text { repayment on a woman with limited resources. Nevertheless, } \\
\text { the loan provided should be large enough to meet the needs } \\
\text { of the person. }\end{array}$ \\
\hline \multirow[t]{2}{*}{$\begin{array}{l}\text { Use of insurance } \\
\text { to manage risks }\end{array}$} & $\begin{array}{l}\text { Kazianga \& } \\
\text { Wahhaj, } 2020\end{array}$ & $\begin{array}{l}\text { Empirical: } \\
\text { Mixed }\end{array}$ & No & Burkina Faso & $\begin{array}{l}\text { Rainfall index insurance can complement informal risk- } \\
\text { sharing networks. }\end{array}$ \\
\hline & $\begin{array}{l}\text { Bauchet et al. } \\
2017\end{array}$ & Empirical & $\begin{array}{l}\text { Bundling of } \\
\text { insurance products }\end{array}$ & Colombia & $\begin{array}{l}\text { Bundling micro-loans with crop insurance can enhance the } \\
\text { uptake of insurance and financial inclusion. However, the } \\
\text { permanent crop and cash crop producers have different } \\
\text { uptake with voluntary bundling of insurance products. }\end{array}$ \\
\hline \multicolumn{6}{|c|}{ Widow, female-headed } \\
\hline \multirow{2}{*}{$\begin{array}{l}\text { Decision-making } \\
\text { and } \\
\text { entrepreneurial } \\
\text { behaviour } \\
\text { differences } \\
\text { between female- } \\
\text { headed and male- } \\
\text { headed } \\
\text { households }\end{array}$} & $\begin{array}{l}\text { Acheampong } \\
2018\end{array}$ & Empirical & $\begin{array}{l}\text { Resource based } \\
\text { theory and gender } \\
\text { theory }\end{array}$ & Ghana & $\begin{array}{l}\text { Having access to microfinance removes barriers for financial } \\
\text { resources in entrepreneurial activities. The findings } \\
\text { demonstrate that female-led families are more likely to have } \\
\text { better returns to microfinance than their male counterparts. } \\
\text { This is due to only women with capacity to manage } \\
\text { businesses obtaining loans. }\end{array}$ \\
\hline & $\begin{array}{l}\text { Theophilus } \\
\text { and Paul } 2019\end{array}$ & Empirical & $\begin{array}{l}\text { Women's agency } \\
\text { for decision making }\end{array}$ & Ghana & $\begin{array}{l}\text { Participation of village level savings and loan groups enhance } \\
\text { the agency of females. }\end{array}$ \\
\hline
\end{tabular}


Online supplementary: Summary of the articles

\begin{tabular}{|c|c|c|c|c|c|}
\hline \multicolumn{6}{|c|}{ Online supplementary: Summary of the articles } \\
\hline $\begin{array}{c}\text { Category and } \\
\text { theme }\end{array}$ & Article & $\begin{array}{l}\text { Type of } \\
\text { article }\end{array}$ & $\begin{array}{c}\text { Theory or } \\
\text { conceptual framing }\end{array}$ & Country & Key findings \\
\hline \multicolumn{6}{|c|}{ Youth and younger women and microfinance } \\
\hline \multirow[t]{3}{*}{$\begin{array}{l}\text { Role of savings } \\
\text { groups/savings } \\
\text { and loan } \\
\text { associations }\end{array}$} & $\begin{array}{l}\text { Flynn \& } \\
\text { Sumberg, } \\
2018\end{array}$ & Emp & $\begin{array}{l}\text { Financial inclusion } \\
\text { and livelihoods of } \\
\text { poor young people }\end{array}$ & $\begin{array}{l}4 \text { countries } \\
\text { (Tanzania, } \\
\text { Ghana, } \\
\text { Uganda and } \\
\text { Zambia) }\end{array}$ & $\begin{array}{l}\text { Youth savings groups facilitate small scale income-generating } \\
\text { activities. Microfinance services are used to cover } \\
\text { operational expenses and to manage cash flow rather than } \\
\text { for investment-related expenses. }\end{array}$ \\
\hline & $\begin{array}{l}\text { Flynn \& } \\
\text { Sumberg, } \\
2017\end{array}$ & Empirical & $\begin{array}{l}\text { Financial inclusion } \\
\text { and livelihoods of } \\
\text { poor young people }\end{array}$ & $\begin{array}{l}4 \text { countries } \\
\text { (Tanzania, } \\
\text { Ghana, } \\
\text { Uganda and } \\
\text { Zambia) }\end{array}$ & $\begin{array}{l}\text { The young people's engagement with savings groups is an } \\
\text { embedded practice in their family and wider social networks. } \\
\text { They use sharing, cooperation, joint action, and co- } \\
\text { investment activities when managing entrepreneurial } \\
\text { financial resources. }\end{array}$ \\
\hline & $\begin{array}{l}\text { Lowicki-Zucca } \\
\text { et al., } 2014\end{array}$ & Empirical & Inclusion & Uganda & $\begin{array}{l}\text { Village level savings and loan groups can be used to reduce } \\
\text { the vulnerabilities of household and benefit children and } \\
\text { their protection. }\end{array}$ \\
\hline \multicolumn{6}{|c|}{ Refugees } \\
\hline \multirow{2}{*}{$\begin{array}{l}\text { Rebuilding } \\
\text { livelihoods } \\
\text { through } \\
\text { microfinance }\end{array}$} & $\begin{array}{l}\text { Colgan \& } \\
\text { Kolínský, } 2014\end{array}$ & Empirical & $\begin{array}{l}\text { Alternative } \\
\text { collateral and } \\
\text { statelessness }\end{array}$ & Nepal & $\begin{array}{l}\text { Microfinance programmes need to be customised to specific } \\
\text { situations. These efforts then can create feasible, positive, } \\
\text { long-term effects among refugees. }\end{array}$ \\
\hline & Idris 2019 & Empirical & $\begin{array}{l}\text { Mixed } \\
\text { embeddedness }\end{array}$ & US & $\begin{array}{l}\text { Refugees, who use microfinance and entrepreneurial } \\
\text { support, create jobs for themselves, their families, and } \\
\text { for others in their communities. This helps them to use their } \\
\text { mixed-embedded contextual practices and integrate into the } \\
\text { community. }\end{array}$ \\
\hline
\end{tabular}




\begin{tabular}{|c|c|c|c|c|c|}
\hline \multicolumn{6}{|c|}{ Online supplementary: Summary of the articles } \\
\hline $\begin{array}{c}\text { Category and } \\
\text { theme }\end{array}$ & Article & $\begin{array}{l}\text { Type of } \\
\text { article }\end{array}$ & $\begin{array}{c}\text { Theory or } \\
\text { conceptual framing }\end{array}$ & Country & Key findings \\
\hline \multicolumn{6}{|c|}{ Cisgender and transgender } \\
\hline $\begin{array}{l}\text { Intention of } \\
\text { starting a } \\
\text { business with } \\
\text { microfinance }\end{array}$ & $\begin{array}{l}\text { Lall et al., } \\
2017\end{array}$ & Empirical & \begin{tabular}{|l|} 
Interventions \\
preventing HIV \\
transmission
\end{tabular} & Malaysia & $\begin{array}{l}\text { Cisgender and transgender woman sex workers are } \\
\text { interested in starting businesses. Training programs and } \\
\text { financial literacy sessions, and not just credit, need to be part } \\
\text { of the package to ensure a smooth transition from sex work } \\
\text { to self-employment. However, perceived transphobia, } \\
\text { stigma, and lack of resources could be barriers for self- } \\
\text { employment. }\end{array}$ \\
\hline
\end{tabular}

